University of Louisville

ThinkIR: The University of Louisville's Institutional Repository

Electronic Theses and Dissertations

$12-2018$

\title{
Framing climate change as national security: a survey-experiment on climate change perceptions.
}

Adam Lyons

University of Louisville

Follow this and additional works at: https://ir.library.louisville.edu/etd

Part of the American Politics Commons, Climate Commons, and the Political Theory Commons

\section{Recommended Citation}

Lyons, Adam, "Framing climate change as national security: a survey-experiment on climate change perceptions." (2018). Electronic Theses and Dissertations. Paper 3086.

https://doi.org/10.18297/etd/3086

This Master's Thesis is brought to you for free and open access by ThinkIR: The University of Louisville's Institutional Repository. It has been accepted for inclusion in Electronic Theses and Dissertations by an authorized administrator of ThinkIR: The University of Louisville's Institutional Repository. This title appears here courtesy of the author, who has retained all other copyrights. For more information, please contact thinkir@louisville.edu. 
FRAMING CLIMATE CHANGE AS NATIONAL SECURITY: A SURVEY-EXPERIMENT ON CLIMATE CHANGE PERCEPTIONS

\author{
By \\ Adam Lyons \\ B.S., University of Louisville, 2011 \\ A Thesis \\ Submitted to the Faculty of the \\ in Partial Fulfillment of the Requirements \\ for the Degree of \\ Master of Arts \\ in Political Science \\ Department of Political Science \\ University of Louisville \\ Louisville, Kentucky
}

College of Arts and Sciences of the University of Louisville

December 2018 
Copyright 2018 by Adam Lyons

All rights reserved 

FRAMING CLIMATE CHANGE AS NATIONAL SECURITY:

A SURVEY-EXPERIMENT ON CLIMATE CHANGE PERCEPTIONS

\author{
By \\ Adam Lyons \\ B.A., University of Louisville, 2011
}

A Thesis Approved on

November 30, 2018

by the following Thesis Committee:

Dr. Jason Gainous

Dr. Laura Moyer

Dr. Margaret D'Silva 


\section{DEDICATION}

This thesis is dedicated to my wife, Jenita and daughters, Olivia and Esma whose patience, motivation, and inspiration made this journey possible. 


\section{ACKNOWLEDGEMENTS}

I would like to thank my committee chair Dr. Jason Gainous for guiding and challenging me from the conception of this thesis to the finished product. Dr. Gainous' expertise has been invaluable throughout this process. I would also like to thank my second reader Dr. Laura Moyer for providing guidance and support with this project and throughout my graduate education. I am also thankful to my third reader Dr. Margaret D'Silva who brought a unique perspective to my research and offered very helpful critical feedback that improved my thesis.

I would also like to acknowledge the University of Louisville Department of Political Science for providing me a graduate research grant to cover a bulk of the expense needed to carryout the survey-experiment in this thesis. 


\begin{abstract}
FRAMING CLIMATE CHANGE AS NATIONAL SECURITY: A SURVEY-EXPERIMENT ON CLIMATE CHANGE PERCEPTIONS
\end{abstract}

\title{
Adam Lyons
}

November 30, 2018

The issues surrounding climate change continue to have polarizing effects on many Americans. In this thesis I offer a potential bridge to this divide with a comprehensive study on how issue frames can impact how individuals shape their opinions on environmental issues. Focusing on a national security frame, I ask the central research "Will the public perceive issues of climate change differently when they are framed as threats to national security?" For this thesis I design an original experimental survey to measure the impact security framing has on participants' perception of both climate change and environmental policy options. The survey was designed using Qualtrics online survey software and I recruited participants using Amazon's Mechanical Turk crowd-sourced labor platform. I use data from this original framing experiment to show that exposure to a national security frame does, indeed, affect perceptions on environmental issues and raise support for environmental policies. 
TABLE OF CONTENTS

PAGE

DEDICATION................................................................

ACKNOWLEDGEMENTS ............................................... iv

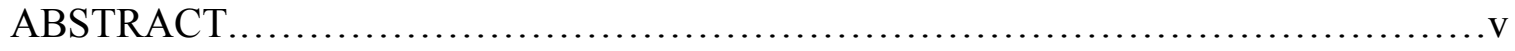

LIST OF FIGURES......................................................vii

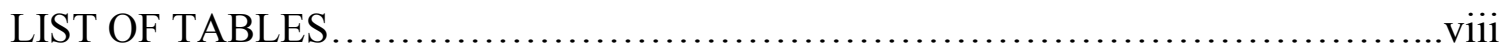

CHAPTER I: INTRODUCTION..........................................

CHAPTER II: LITERATURE REVIEW ....................................4

CHAPTER III: DESCRIPTIVE STATISTICS .................................

CHAPTER IV: DESIGN AND METHOD...................................... 19

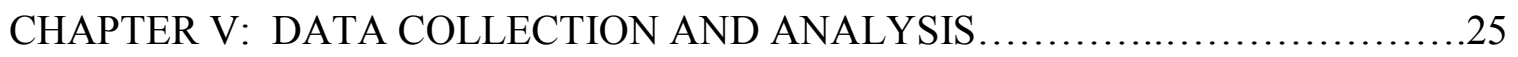

CHAPTER VI: DISCUSSION AND CONCLUSION ...........................46

REFERENCES ........................................................... 54

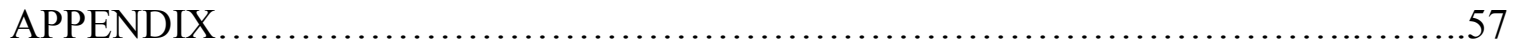

CURRICULUM VITAE...................................................6 67 


\section{LIST OF FIGURES}

FIGURE

PAGE

5.1 Distribution of Political Ideology between Experiment Groups...........27

5.2 Distribution of Gender between Experiment Groups....................28

5.3 Distribution of Race between Experiment Groups.....................29

5.4 Distribution of Age between Experiment Groups........................ 30

5.5 Distribution of Education between Experiment Groups..................31 


\section{LIST OF TABLES}

TABLE

PAGE

3.1 Federal Budget Spending: Protecting the Environment, by Party ID.....15

3.2 Federal Budget Spending: Protecting the Environment, by Political Ideology....................................................16

7pt Scale Environmental-Jobs Tradeoff, by Party ID..................17

7pt Scale Environmental-Jobs Tradeoff, by Political Ideology...........18

5.1. Results of t-test and Descriptive Statistics for Climate-Security, by Experiment Group..............................................34

5.2. Results of t-test and Descriptive Statistics for Policy-Action, by

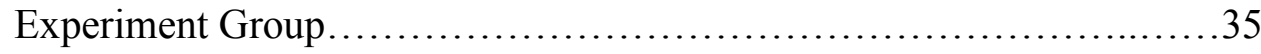

5.3. Results of t-tests and Descriptive Statistics Climate-Security and PolicyAction, by Experiment Group, controlled for Political Ideology..........37

5.4. Results of t-tests and Descriptive Statistics Climate-Security and PolicyAction, by Experiment Group, controlled for Gender................... 38

5.5. Results of t-tests and Descriptive Statistics Climate-Security and PolicyAction, by Experiment Group, controlled for

Race.

5.6. Results of t-tests and Descriptive Statistics Climate-Security and PolicyAction, by Experiment Group, controlled for

Age. ... .40

5.7. Results of t-tests and Descriptive Statistics Climate-Security and PolicyAction, by Experiment Group, controlled for

Education....

5.8. Results of OLS Regression Model on Support for Climate-Security and Policy-Action by Control Variables. 


\section{CHAPTER I}

\section{INTRODUCTION}

As the debate over climate change continues to divide Americans, primarily along partisan lines, media messaging and the framing strategies used may be partially responsible for this division. After rebranding "global warming" to the more comprehensive term of "climate change," advocates on both sides of the climate change debate have used varying policy frames to define the narrative environmental problems, or the lack of problems, to align with policies that further their political agendas. One frame that seems to be gaining steam among policy actors and the media is to portray the dire effects of climate change as an issue of national security. Environmental advocates and military leaders are in near agreement that disaster-mitigating policies are necessary for the protection of both national and international security. Placing a security frame on issues related to climate change has been a strategy used in the highest level of American government. What was once a pillar of the Obama administration's National Security Strategy, the Trump administration omitted climate change as a threat to national security when they issued their first National Security Strategy in January $2017 .{ }^{1}$ This shift in the executive-level framing of climate change provides numerous research opportunities to

\footnotetext{
${ }^{1}$ For the Obama Administration National Security Strategy see: https://obamawhitehouse.archives.gov/sites/default/files/docs/2015_national_security_strategy_2.pdf, For the Trump Administration National Security Strategy see: https://www.whitehouse.gov/wpcontent/uploads/2017/12/NSS-Final-12-18-2017-0905.pdf
} 
examine how the framing of climate change issues by media outlets, politicians, and interest groups affect public perceptions. Does the public perceive issues of climate change as more severe when they are framed as threats to national security? Does public support government action on climate change increase when policy options are framed as necessities for maintaining national security? These two questions, together, comprise the central research question this thesis seeks to address.

To answer these questions, I design an original framing experiment that randomly assigns a large $\mathrm{N}$, crowdsourced sample to read one of two news excerpts prior to answering questions related to climate change, national security, and policy. The treatment excerpt frames climate change as an issue of national security, while the control excerpt contains no framing, outside of the original article from which the excerpt is taken. The literature reviewed in this thesis provides a strong theoretical foundation to build predictions on the likely results this experiment may report.

Issues surrounding climate change have been contentious and publicly polarizing since they first landed on the public agenda (Dunlap and McCright 2011). The mobilization of both environmental advocacy groups and corporate interests (McCright and Dunlap 2000) and coordinated efforts in casting blame when an environmental disaster occurs (Merry 2014) have been successful strategies in rallying support bases and shaping public opinions of climate change. However, these efforts are likely adding to an already hyper-polarized issue. This thesis seeks a possible bridge to this divide by offering research on a frame that may reduce the polarizing effects of climate change. If the participants of this study react positively to the security frame, they may be more likely to change their perception of climate change as a matter of national security. 
Moreover, if the security frame changes perceptions of climate change it may have the additional effect of increasing action on policy options.

The layout of this thesis is designed to provide a comprehensive coverage of the relevant social science literature, the experimental design and methods used for data collection, and how the data were analyzed. Chapter II reviews the relevant social science literature, such as policy issue framing and problem definition theory, media choice, environmental and national security public opinion, and public policy agenda setting. I discuss how each area of research builds a theoretical foundation for this thesis. Chapter III provides a brief overview of public opinion on environmental issues captured in the 2016 American National Election Study (ANES). A series a data tables examine views on environmental issues from respondents across the political spectrum. Chapter IV outlines the research design and method and measurement this thesis deploys to test the hypotheses introduced in this chapter. The use of a survey experiment, the digital survey software Qualtrics, and Amazon's online labor force for recruiting survey participants ("MTURK") are also examined. Chapter V presents a series of statistical models that test the effects of the framing experiment on a large $\mathrm{N}$, randomly assigned sample. This thesis concludes with a final chapter, Chapter VI, that discusses the implications of this study and opportunities for future research based on the findings presented in this thesis. 


\section{CHAPTER II}

\section{LITERATURE REVIEW}

This chapter provides a review of the literature used to develop the theoretical framework of this thesis. First, I discuss the theory of issue framing and its effects on influencing individual attitudes. Next, I examine research on the attitudes on environmental policies and the factors that contribute to these attitudes. Similar to the review on environmental policies, I then examine literature on attitudes toward national security with a particular emphasis on the public's attitude of importance in security issues. I then review recent research showing the connection between environmental issues and national security. Finally, I review policy agenda setting literature with an emphasis on policy framing and narratives. Following this review, I formally state and justify my primary hypotheses.

\section{Issue Framing Theory}

Issue frames are both common and essential communications strategies that organize everyday reality into succinct narratives (Tuchman 1978). Recent research into the effects of media issue framing on individual attitudes has focused on the ways in which the media play a role in the construction of reality (McQuail 1994; Scheufele 1999). In a time where information consumers have seemingly endless amounts of media outlets to choose from, media is becoming increasingly tailored to fit an individual's political ideology and social preferences, often without the consumer's knowledge 
(Drotner, 2005). The public can now consume media that is only relevant to them and ignore what is not. This combination of the media's ability to construct reality and personalized news and information sources leads individuals toward a reality that is built not just on personal experiences and interactions with peers, but on their interpretations of the media they have consumed (Drotner, 2005; Keeter, 1993; Scheufele, 1999).

Media outlets, politicians and advocacy groups are at an advantage when they frame stories in a way that garners a lot of public attention. These policy actors often focus on high-stakes issues, as they are believed to be the most newsworthy, all of which leads to increased viewership and exposure (Bennett, 1996; Boydston \& Glazier, 2013; Gans 2004). This leads media outlets to frame stories in a more negative or loss frame than a positive or gain frame and thus sensationalizing the story (Boydston \& Glazier, 2013; Sheafer, 2007). This practice represents the media strategy of "if it bleeds, it leads" when deciding on which stories to run. In addition to loss versus gain media framing, media outlets have seen increase viewership when stories are framed in such a way that plays off an individual's fear (Boydston \& Glazier, 2013; Gans, 2004; Iyengar, 1991, 1996).

Additional research on media and public opinion has shown that news headlines alone can have a powerful effect on the attitudes people adopt on issues by providing cognitive shortcuts, or heuristics, (Allport \& Lepkin, 1943; Geer \& Kahn, 1993; Pfau, 1995; Smith \& Fowler, 1982; Tannenbaum,1953) even when there is considerable dissonance between the headline and its corresponding story (Andrew, 2007). I utilize these findings in the design of the survey experiment by providing the treatment group with a national security frame in the headline, as well as the body. 
This research on media and the strategic use of issue frames builds the position of this thesis that a national security frame on climate change will affect the public's perception on climate change's impacts. Obviously, issues of national security rank fairly high in sensationalism, making such a frame advantageous for media outlets, politicians, and issue advocacy groups. Furthermore, for an issue to be immune to the barriers established with personalized media sources and crowd-sourced social media, issues will likely have to take on frames that invoke fear or play off other national anxieties. A national security frame on climate change may produce such an effect.

\section{Environmental Attitudes and Media Frames}

Media communications specific to environmental policies are often framed as achievement of gains or avoidance of losses; individuals can make radical choices when they are presented with the opposing frame (Bertolotti \& Catellani, 2014; Gifford \& Comeau, 2011; Reber \& Berger, 2005). In particular, media frames that suggest the achievement of a high level of gains predict an increase in support for environmental policies (Bertolotti \& Catellani, 2014; Morton, Rabinovich, Marshall, \& Bretschneider, 2011). It is my intention to frame environmental policy in this same manner, of gains vs losses, but with the added focus on national security implications.

Additional research suggests that conservatives are, in general, less concerned about the environment and are less likely to support pro-environment policies than liberal leaning individuals (Abramowitz, 1980; Dunlap \& McCright, 2000, 2011; McCright, Dunlap, \& Marquart-Pyatt, 2016). However, this lack of environmental concern is more particular to American conservatives than their international conservatives (McCright, Dunlap, \& Marquart-Pyatt, 2016). Conservatives in other Western countries such as the 
UK, Canada, and Australia have historically lacked similar negative views on climate change (Brechin, 2010; Leiserowitz, 2008). In America, generally the most consistent predictors of environmental support are political ideology and party identification (Konisky, Milyo, \& Richardson, 2008). Additionally, research shows that proenvironmental populations such as the young, racial minorities, and the well-educated, are not typically associated with the Republican Party or conservative ideology, whereas more religious individuals tend to be less supportive (Carman, 1998; Guth, Green, Kellstedt, \& Smidt, 1995; Kanagy, Humphrey, \& Firebaugh, 1994; Klineberg, McKeever \& Rothenbach, 1998; Konisky el al, 2008; Dunlap \& McCright, 2011; Xiao \& Dunlap 2007). This research suggests that the framing experiment employed in this thesis may have profound effects across political ideology, especially if the frame is able to raise support among populations where it traditionally lacks. Chapter III goes a bit further in explaining the political polarization surrounding environmental issues by presenting political descriptive statistics on environmental support.

While a security frame has yet to be tested, the use of different media frames when discussing environmental issues have had varying results. Frames that are expected to be responsive to conservatives, such as religious morality and economic efficiency, have not been shown to affect a change in support for environmental issues (Severson and Coleman, 2015). Through the process of this review, I have yet to find any experiments that test the effects of a national security frame on environmental perceptions, therefore this research will contribute to theory on media framing and attitudes on the environment. A significant change in the perception of climate change among traditionally conservative demographics would represent a large impact of the 
security frame, because these are the groups that may be the most skeptical in terms of the environment.

\section{National Security Framing and Public Opinion}

Research into the importance that national security implications have on voter attitudes has shown a steady increase in support for policies that mitigate the risks of a negative national security impact. Globalization, international uncertainty and greater interconnectedness give national security issues a greater importance in the minds of voters more so now than in the past (Aldrich, Gelpi, Feaver, Reifler, \& Sharp, 1989; Brooks, Dodson, \& Hotchkiss, 2010; Smith, 1996). Moreover, individuals tend to rally around politicians, and their policies, in times where the risks of adverse effects to national security are high (Brooks et al 2010; Mueller 1970). For example, in the 2008 general election, national security issues relating to defense spending, terrorism, and the Iraq war had a substantial influence on voting behavior (Brooks et al 2010). In general,

conservative individuals tend to assign greater importance in national security issues and conservative politicians and media outlets are more likely to emphasize stories with a strong frame of national security (Konisky et al, 2008). This conservative focus on national security suggests such a frame on climate change may affect their perceptions on the issues.

As previously noted, media outlets have an economic advantage in producing news stories that focus on negative frames that invoke fear in the consumer. Framing news stories in terms of national security provides politicians greater access to the media, and thus to voters; as media outlets are more inclined to report such stories (Brooks, et al 2010). Based on this increased focus on national security and the preferential treatment 
given by media outlets, I can reasonably expect that when framing environmental issues in terms of the adverse risk to national security, the public will be more supportive of the mitigating policies. However, there must first be a clear link between pro-environmental policies and reducing the risk of negative national security issues.

\section{Environment as National Security}

Viewing environmental policies in terms of national security is a relatively new practice for researchers, politicians, the media and the public. It was not until the late 20th century that researchers began to examine the potential for environmentally escalated violence and the greater possibility of international conflicts such as resource wars over oil, natural gas, water, etc. (Gleick, 1991; Homer-Dixon, 1999; Matthew, 2000). By the early twenty-first century, the magnitude and implications of humangenerated environmental change have had significant influences on the theory and practice of national security (Matthew, 2000). Scholars and national security experts have since been drawing a clearer connection between environment and security. Research has found that environmental degradation poses a direct threat to national security, putting lives, national welfare and emergency preparedness in danger (Levy, 1995). By drawing this clear connection in the media frames on environmental policy, this thesis expects to find that participants in my survey experiment on the effects of framing will rely on this connection, or heuristic, when determining their attitudes of such policies, leading to increased attention on the policy agenda.

\section{Issue Frames in Agenda Setting}

Another key objective of this project was to examine the policy implications of issue framing. If framing theory suggests frames can affect individual's perception of 
reality, theories born out of policy studies may shed light on how frames affect policy decisions. The literature on agenda setting in the public policy process places a heavy emphasis on the narrative, or frame, of the public policy problem. Framing the basic underlining nature of the problem plays a strong role in determining the level of public attention and action (Rochefort \& Cobb, 1993). Rochefort and Cobb (1993) break down the nature of a problem into five concepts: Severity, Incidence, Novelty, Proximity, and Crisis. Framing climate change with a narrative of its national security implications allows the nature of the problem to fit neatly within these concepts. If raising sea levels, for example, are framed as threats to military readiness the public may perceive this particular implication of climate change as more severe, possibly even a crisis. Aside for the nature of the problem itself, Rochefort and Cobb (1993) also placed emphasis on the nature of the solution as any potential solution must be achievable. A security frame on the nature of the problem may force a shift in framing the potential solutions to climate change's impacts. Solutions framed to be a protection of military infrastructure may be viewed by the public as more achievable, thereby raising public support.

A potential problem for environmental advocates in framing climate change as a severe threat is that there is no singular "villain" to assign blame. When looking to assign blame to problems that may seem out of government's control, causal stories that portray risk, such as a national security risk, present a strong strategic advantage for policy actors to move issues from the accident realm to the realm of purpose, either as an intentional or inadvertent cause (Merry, 2014; Stone, 1989). Rather than being viewed as a force majeure, this shift in the causal narrative allows policy actors to tackle a public problem that previously seemed unachievable. 
Framing issues in a way that promotes the severity of the problem may raise public awareness, however awareness does not always lead to meaningful change. Specific to climate change and the environment, Downs (1972) argues that mass media coverage of environmental issues reinforces the cyclical patterns of the Issue Attention Cycle. This cycle is characterized by five stages: (1) a pre-problem stage that leads to (2) a period of alarmed discovery and euphoric enthusiasm when (3) the public realizes the cost of progress which leads to (4) a gradual decline of interest and ends in the (5) postproblem stage where public attention has diminished, however incremental policy changes have been spurred (Downs, 1972). McComas and Shanahan (1999) tracked environmental media frames through each stage of the issue attention cycle and found that a narrative of consequences and danger dominated the early stages of the cycle, but then gave way to other frames, economic and scientific, as the environmental issues progressed through the attention cycle (McComas \& Shanahan, 1999). However, Downs' framework was published well before the media and policy actors began linking the threats of climate change with direct risks to national security and this strategy of “problem surfing” (Boscarino, 2009) may provide for greater opportunities to advocates of environmental policies to control the public agenda. Boscarino (2009) finds evidence that when advocacy groups prefer a specific solution they will attach it to different problems as alternative problems gain public awareness. A strategy of framing climate change as national security may provide advocacy groups and politicians additional sets of problems to attach their preferred policy action.

The review of the literature in this chapter lays the theoretical foundation for this thesis. To answer the question of whether a national security frame affects people's 
perception of climate change, I rely on the theories developed in the issue framing and media literature to build the basis for the first hypothesis this thesis seeks to test:

Hypothesis 1: When presented with the treatment frame of national security, survey participants are more likely to agree with statements in support of climate change as an issue of national security.

I also test the effects of a national security frame on individual's preference for policy actions. Literature on policy agenda setting suggests that when issues are framed with severe consequences that demand public action, the public is likely to keep this issue in the public arena and on the policy agenda. This leads to the second hypothesis of this thesis:

Hypothesis 2: When presented with the treatment frame of national security survey participants will increase their level of support for specific policy choices.

An issue frame that cannot shift perceptions and motivate the public to act has little use to issue messengers. However, as prior research suggests, framing an issue such as climate change as a matter of national security is predicted in this thesis to change public views of climate change and increase support of specific policy options. Secondary tests will be conducted to see if the impact of any framing effects on subsets of survey experiment participants. Before proceeding to the design and methods of this 
study, the following chapter reports descriptive statistics on environmental public opinion captured in the 2016 American National Election Study. These data, along with study findings reviewed in this chapter provide a good indication of how certain demographics will be affected by national security treatment frame. 


\section{CHAPTER III \\ DESCRIPTIVE STATISTICS}

Aside from the literature on demographics of environmental advocates and critics reviewed in Chapter II, I also present this brief chapter that looks specifically at environmental public opinion along America's political divisions. I use data from the American National Election Studies (ANES) 2016 Time Series Study to analyze public opinion on environmental issues based on both political ideology and party identification. The first public opinion variable measured respondents' view on whether the federal budget spending on the environment should be increased, decreased, or kept the same. The following variable measured participant's opinion on business regulation as a method of protecting the environment and creating jobs. On a seven-point scale, respondents were asked to place themselves between 1. "Regulate business to protect the environment and create jobs," and 7. "No regulations because it will not work and cost jobs". In tables 3.1 through 3.4 I show the frequency and percentage for both political ideology and party identification on the public opinion variables.

Throughout this chapter each table reports a highly significant chi-square statistic showing that there is no independence between political and environmental variables. Tables 3.1 and 3.2 report the public opinion frequencies among political ideology and party identification as it relates to federal budget spending on the environment. These tables present a clear indication that liberals and Democrats are far more supportive of 
increases in environmental spending. Nearly $65 \%$ if Democrats believe federal environmental spending should either increase or be kept the same. This number increases over $99 \%$ when respondents identify as extremely liberal. Independents showed similar support as Democrats, with less than $12 \%$ believing spending should be decreased.

Table 3.1

Federal Budget Spending: Protecting the Environment, by

\begin{tabular}{lccc} 
& \multicolumn{3}{c}{ Party ID } \\
\cline { 2 - 4 } & Democrat & Republican & Independent \\
& $\mathrm{N}=1,446$ & $\mathrm{~N}=1,224$ & $\mathrm{~N}=1,356$ \\
\hline 1. Increase & 1,050 & 371 & 730 \\
& $40.61 \%$ & $30.31 \%$ & $53.83 \%$ \\
2. Decrease & 48 & 335 & 159 \\
& $3.32 \%$ & $27.37 \%$ & $11.73 \%$ \\
3. Kept the & 348 & 518 & 467 \\
same & $24.07 \%$ & $42.32 \%$ & $34.44 \%$ \\
\hline
\end{tabular}

Pearson's Chi-Square $=579.28, \mathrm{p}<0.001$

Opinions on environmental spending do not share nearly the same support among conservatives and Republicans. Nearly $70 \%$ of Republicans would prefer a decrease or no change in environmental spending, with over $50 \%$ of extremely conservative respondents believe spending should be decreased. Even those less extreme, who identify as slightly conservative and conservative, support decreased spending at higher rates than independents and all liberals. 
Table 3.2

Federal Budget Spending: Protecting the Environment, by Political Ideology

\begin{tabular}{|c|c|c|c|c|c|c|c|}
\hline & $\begin{array}{c}\text { Extremely } \\
\text { liberal } \\
\mathrm{N}=146\end{array}$ & $\begin{array}{l}\text { Liberal } \\
\mathrm{N}=502\end{array}$ & $\begin{array}{l}\text { Slightly } \\
\text { liberal } \\
\mathrm{N}=380\end{array}$ & $\begin{array}{l}\text { Moderate } \\
\mathrm{N}=891\end{array}$ & $\begin{array}{c}\text { Slightly } \\
\text { conservative } \\
\mathrm{N}=506\end{array}$ & $\begin{array}{c}\text { Conservative } \\
\qquad \mathrm{N}=699\end{array}$ & $\begin{array}{c}\text { Extremely } \\
\text { Conservative } \\
\mathrm{N}=165\end{array}$ \\
\hline 1. & 134 & 413 & 265 & 521 & 210 & 141 & 37 \\
\hline Increase & $91.78 \%$ & $82.27 \%$ & $69.74 \%$ & $58.47 \%$ & $41.50 \%$ & $20.17 \%$ & $22.42 \%$ \\
\hline 2. & 1 & 8 & 13 & 60 & 97 & 244 & 84 \\
\hline Decrease & $0.68 \%$ & $1.59 \%$ & $3.42 \%$ & $6.73 \%$ & $19.17 \%$ & $34.91 \%$ & $50.91 \%$ \\
\hline $\begin{array}{l}\text { 3. Kept } \\
\text { the same }\end{array}$ & $\begin{array}{c}11 \\
7.53 \%\end{array}$ & $\begin{array}{c}81 \\
16.14 \%\end{array}$ & $\begin{array}{c}102 \\
26.84 \%\end{array}$ & $\begin{array}{c}310 \\
34.79 \%\end{array}$ & $\begin{array}{c}199 \\
39.33 \%\end{array}$ & $\begin{array}{c}314 \\
44.92 \%\end{array}$ & $\begin{array}{c}44 \\
26.67 \%\end{array}$ \\
\hline
\end{tabular}

Tables 3.3 and 3.4 report the frequencies on the 7-point environment-jobs tradeoff scale that measures respondents' opinion on regulating businesses to protect the environment and create jobs. Similar to the descriptive statistics in tables 3.1 and 3.2, support for business regulation is divided along political and party lines. A large majority of Democrats are at the top one-third of the scale, with over $75 \%$ expressing support for regulating business to protect the environment and create jobs. Respondents who identify as slightly to extremely liberal are just as supportive. Less than $1 \%$ in each liberal category believe that there should be no regulations because they do not work and cost jobs. While still relatively supportive, independents are clustered more toward the middle of the scale, with nearly $50 \%$ in the middle one-third.

Again, conservatives and Republicans reported the lowest levels of support for business regulation. Only $10 \%$ of Republicans support regulation at the highest level, whereas over $40 \%$ place themselves at the bottom one-third of the scale believing 
regulations do not work and cost jobs. By ideology, no conservative category reached $15 \%$ for the highest level of support for regulations. Slightly to extremely conservative respondents each report strong majorities at bottom half of the scale.

Table 3.3

7pt Scale Environmental-Jobs Tradeoff, by Party ID

\begin{tabular}{|c|c|c|c|}
\hline & $\begin{array}{l}\text { Democrat } \\
\mathrm{N}=1,215\end{array}$ & $\begin{array}{c}\text { Republican } \\
\mathrm{N}=1,033\end{array}$ & $\begin{array}{c}\text { Independent } \\
\mathrm{N}=1,131\end{array}$ \\
\hline 1. Regulate & 473 & 110 & 262 \\
\hline $\begin{array}{l}\text { business to } \\
\text { protect the } \\
\text { environment } \\
\text { and create } \\
\text { jobs }\end{array}$ & $38.93 \%$ & $10.65 \%$ & 23.17 \\
\hline 2. & $\begin{array}{c}274 \\
22.55 \%\end{array}$ & $\begin{array}{c}97 \\
9.39 \%\end{array}$ & $\begin{array}{c}216 \\
19.10\end{array}$ \\
\hline 3. & $\begin{array}{c}184 \\
15.14 \%\end{array}$ & $\begin{array}{c}151 \\
14.62 \%\end{array}$ & $\begin{array}{c}211 \\
18.66\end{array}$ \\
\hline 4. & $\begin{array}{c}175 \\
14.40 \%\end{array}$ & $\begin{array}{c}235 \\
22.75 \%\end{array}$ & $\begin{array}{c}228 \\
20.16\end{array}$ \\
\hline 5. & $\begin{array}{c}52 \\
4.28 \%\end{array}$ & $\begin{array}{c}175 \\
16.94 \%\end{array}$ & $\begin{array}{l}102 \\
9.02\end{array}$ \\
\hline 6. & $\begin{array}{c}32 \\
2.63 \%\end{array}$ & $\begin{array}{c}165 \\
15.97 \%\end{array}$ & $\begin{array}{c}94 \\
5.66\end{array}$ \\
\hline $\begin{array}{l}\text { 7. No } \\
\text { regulations } \\
\text { because it will } \\
\text { not work and } \\
\text { cost jobs. }\end{array}$ & $\begin{array}{c}25 \\
2.06 \%\end{array}$ & $\begin{array}{c}100 \\
9.68 \%\end{array}$ & $\begin{array}{c}48 \\
4.24\end{array}$ \\
\hline
\end{tabular}




\section{Table 3.4}

7pt Scale Environmental-Jobs Tradeoff, by Political Ideology

\begin{tabular}{|c|c|c|c|c|c|c|c|}
\hline & $\begin{array}{c}\text { Extremely } \\
\text { liberal } \\
\mathrm{N}=138\end{array}$ & $\begin{array}{l}\text { Liberal } \\
\mathrm{N}=469\end{array}$ & $\begin{array}{l}\text { Slightly } \\
\text { liberal } \\
\mathrm{N}=348\end{array}$ & $\begin{array}{l}\text { Moderate } \\
\qquad \mathrm{N}=766\end{array}$ & $\begin{array}{c}\text { Slightly } \\
\text { conservative } \\
\mathrm{N}=466\end{array}$ & $\begin{array}{c}\text { Conserv } \\
\text { ative } \\
\mathrm{N}=632\end{array}$ & $\begin{array}{c}\text { Extremely } \\
\text { Conservative } \\
\mathrm{N}=147\end{array}$ \\
\hline $\begin{array}{l}\text { 1. Regulate } \\
\text { business to } \\
\text { protect the } \\
\text { environment } \\
\text { and create } \\
\text { jobs }\end{array}$ & $\begin{array}{c}112 \\
81.16 \%\end{array}$ & $\begin{array}{c}215 \\
45.84 \%\end{array}$ & $\begin{array}{c}104 \\
29.89 \%\end{array}$ & $\begin{array}{c}173 \\
22.58 \%\end{array}$ & $\begin{array}{c}65 \\
14.57 \%\end{array}$ & $\begin{array}{c}54 \\
8.54\end{array}$ & $\begin{array}{c}21 \\
14.29 \%\end{array}$ \\
\hline 2. & $\begin{array}{c}14 \\
10.14 \%\end{array}$ & $\begin{array}{c}141 \\
30.06 \%\end{array}$ & $\begin{array}{c}106 \\
30.46 \%\end{array}$ & $\begin{array}{c}139 \\
18.15 \%\end{array}$ & $\begin{array}{c}64 \\
14.35 \%\end{array}$ & $\begin{array}{c}42 \\
6.65\end{array}$ & $\begin{array}{c}6 \\
4.08 \%\end{array}$ \\
\hline 3. & $\begin{array}{c}3 \\
2.17 \%\end{array}$ & $\begin{array}{c}68 \\
14.50 \%\end{array}$ & $\begin{array}{c}80 \\
22.99 \%\end{array}$ & $\begin{array}{c}137 \\
17.89 \%\end{array}$ & $\begin{array}{c}82 \\
18.39 \%\end{array}$ & $\begin{array}{c}72 \\
11.39 \%\end{array}$ & $\begin{array}{c}14 \\
9.52 \%\end{array}$ \\
\hline 4. & $\begin{array}{c}5 \\
3.62 \%\end{array}$ & $\begin{array}{c}25 \\
5.33 \%\end{array}$ & $\begin{array}{c}39 \\
11.21 \%\end{array}$ & $\begin{array}{c}190 \\
24.80 \%\end{array}$ & $\begin{array}{c}111 \\
24.89 \%\end{array}$ & $\begin{array}{c}151 \\
23.89 \%\end{array}$ & $\begin{array}{c}24 \\
16.33 \%\end{array}$ \\
\hline 5. & $\begin{array}{c}0 \\
0.00 \%\end{array}$ & $\begin{array}{c}11 \\
2.35 \%\end{array}$ & $\begin{array}{c}12 \\
3.45 \%\end{array}$ & $\begin{array}{c}63 \\
8.22 \%\end{array}$ & $\begin{array}{c}72 \\
16.14 \%\end{array}$ & $\begin{array}{c}120 \\
18.99 \%\end{array}$ & $\begin{array}{c}20 \\
13.61 \%\end{array}$ \\
\hline 6. & $\begin{array}{c}3 \\
2.17 \%\end{array}$ & $\begin{array}{c}6 \\
1.28 \%\end{array}$ & $\begin{array}{c}4 \\
1.15 \%\end{array}$ & $\begin{array}{c}35 \\
4.57 \%\end{array}$ & $\begin{array}{c}33 \\
7.40 \%\end{array}$ & $\begin{array}{c}128 \\
20.25 \%\end{array}$ & $\begin{array}{c}36 \\
24.49 \%\end{array}$ \\
\hline $\begin{array}{l}\text { 7. No } \\
\text { regulations } \\
\text { because it will } \\
\text { not work and } \\
\text { cost jobs. }\end{array}$ & $0.72 \%$ & $0.64 \%$ & $0.86 \%$ & $3.79 \%$ & $4.26 \%$ & $10.28 \%$ & $17.69 \%$ \\
\hline
\end{tabular}

Pearson's Chi-Square $=1.1 \mathrm{e}+03, \mathrm{p}<0.001$ 
This overview of public opinion relating to environmental issues provides supplemental demographic data to the literature reviewed in Chapter III. Through the ANES data, I am able to build certain assumptions on how participant's political ideology may affect the survey experiment of this thesis. Tables 3.1 through 3.4 have demonstrated that public opinion on environmental issues, such as climate change, are dependent on one's political ideology and political party affiliation. Measuring solely political ideology, I expect this study to find a similar lack of support among conservatives for the climate change and environmental variables used. However, it may be possible that the national security frame in this experiment may boost this support, and if so may produce some of the most significant findings of this thesis. 


\section{CHAPTER IV \\ RESEARCH METHOD AND DESIGN}

To answer the central research question of this thesis posed in Chapter I and to test the hypotheses of this thesis, an original survey experiment was designed using an online labor force, yielding a large $\mathrm{N}$ subject pool with a randomized treatment design. First, this chapter discusses the use of Amazon's Mechanical Turk ("MTURK") and how crowd-sourced “workers” from MTURK were recruited as survey participants. Next, I discuss the design of the experiment, the national security frame, and how survey experiments have become an effective method throughout the social sciences. Finally, I describe the design and deployment of the survey experiment using the digital platform Qualtrics and how the survey is linked to MTURK for experiment participation. This chapter concludes with a discussion on the use of online labor markets for social science research and the merits of a digital workforce and opt-in survey participation.

\section{$\underline{\text { Amazon Mechanical Turk }}$}

The survey-experiment was conducted through Amazon's Mechanical Turk ("MTURK") online crowdsourcing labor platform. MTURK recruits workers to preform Human Intelligence Tasks ("HITs") set up by "Requestors" who offer a reward for the completion of unique tasks. Since MTURK's launch in 2005, it has become the most widely used crowdsourced labor market with citations in over 15,000 published papers over the last 10 years (Chandler \& Shapiro, 2016). This popularity is likely a result of 
MTURK's low cost, easy use, and requiring no interaction between researcher and subjects, or among fellow subjects. This lack of interaction between the researcher and subject may prevent any biases or interference than may corrupt the data through inperson experiments. Furthermore, research has shown similar findings when replicating published, traditional experiments using only MTURK to recruit experiment participants (Berinsky, Huber, \& Lenz, 2012).

The nature of MTURK as an online, opt-in labor market to gather convenience samples does, however, present challenges for researchers. Unless a researcher, or "requestor" pays premium rates for MTURK "Masters", gathering high quality data is out of the control of the researcher. However, research into the demographic makeup of MTURK workers finds that workers have very similar demographics to traditional subject pools, which may provide evidence of generalizability in MTRUK experiments (Paolacci, Chandler, \& Ipeirotis, 2010). However, MTURK workers have been found to be less representative of the US population than internet-based panels or national probability samples (Berinsky et al, 2012). When researchers measure and account for political and demographic data, as I do in this study, MTURK has been shown to produce adequate data for advanced experimental research (Levay, Freese, \& Druckman, 2016). Additional research suggests external validity by finding similar results when survey experiments are conducted on both MTRUK and through traditional methods (Berinsky et al, 2012; Mullinix, Leeper, \& Druckman, 2015). With the rapid growth in popularity as a proper research tool, I am confident MTURK will provide data adequate for this study.

MTURK organizes Human Intelligence Tasks (HITs) in workers' task queue based on preferences such as time, reward, and number of tasks. For this experiment, 
workers were presented with a short description of the study, the "reward", or payment, and the maximum time a worker must complete the HIT, see below:

TITLE:

"Answer a survey about your opinions on climate change."

DESCRIPTION:

"Read a brief news excerpt and give us your opinion about climate change."

REWARD PER ASSIGNMENT

"\$0.50"

TIME ALLOTTED PER ASSIGNMENT

"10 Minutes"

The study was set up to allow exactly 800 unique workers to accept the HIT for a maximum of 21 days before the HIT would automatically expire. ${ }^{2}$ Additional keywords of "survey," "demographics," and "research" were provided to help Workers search for the HIT. MTURK offers the option to request additional qualification of Workers based on a series of demographics and behaviors or require that all Workers be certified as "Masters", a certification that analyzes Workers performance across a wide range of HITs, however selecting these options increases the fee paid to Amazon. In order to keep this study economically feasible, no special qualifications were requested, making the HIT available to all Worker on the platform. ${ }^{3}$ After reading the description, Workers could choose to accept the HIT, which would then direct them to a link containing the

\footnotetext{
${ }^{2}$ As a Requestor, I was required to prepay the entire reward per assignment ( $\$ 0.50 \times 800$ Workers), along with $20 \%$ fee paid to Amazon for each unique HIT ( $\$ 0.20$ x 800 HITs. Due to Worker error, 15 additional surveys, outside of the 800 Workers requested and prepaid, were completed and recorded without the worker officially accepting the HIT in MTURK, therefore 15 workers were left unpaid for their participation.

${ }^{3}$ This study was awarded a graduate research grant form the University of Louisville Department of Political Science to cover a bulk of the MTURK expense.
} 
survey-experiment. Upon completion, Workers were given a randomly generated number to enter into MTURK signaling the completion of the HIT.

\section{Framing Experiment}

The survey experiment began by asking participants to read a brief excerpt from a news article. From there, participants were randomly selected to receive either the control or treatment article. The groups received an excerpt from a real article TIME Magazine's website, TIME.com, by authors Justin Worland and David Johnson from March 2016 titled "See How Your City May Be Affected by Rising Sea Levels." The control group received the first three paragraphs of the article verbatim, with no added frame. The original story does present a loss frame, which is evident in the excerpt received by the control group, however the loss is general with no mention of national security implications.

For the treatment group, I first added a reference to national security directly in the headline. Neither the control nor treatment excerpt contained any source documentation, such as author or publication, as to against any unwanted effect source cues may present. However, Therefore, adding a framing element in the headline received by the treatment group may provide an additional framing effect. The excerpt received by the treatment group included changes in keywords in the body of the text that add a national security frame. Specifically, changes to the original story were made to terms that describe the general population and replaced with terms describing military installations and personnel. Both control and treatment excerpts can be found in the Appendix. Once participants finished reading their randomly assigned excerpt, they were asked to rank their agreement to a series of statements on the relationship between 
climate change and national security, and potential policy actions. The following section describes the aspects of the survey instrument, the design, flow, and deployment in further detail.

The use of human subjects in this experiment required approval from the University of Louisville Institutional Review Board. ${ }^{4}$

\section{Qualtrics Survey}

The survey experiment was designed using Qualtrics online statistical software platform. Qualtrics survey software was launched in 2002 and allows for personalized survey design, external survey link that is scalable for most digital platforms, participant recruitment, and data analytics (Qualtrics.com). The survey was designed using a series of statement and/or question blocks presented individually to the participants. Participants had access to both "previous" and "next" page commands in the event of a mistake or to refer back to any point in the survey. After advancing from the first block, which obtained the participants consent to participate in the study, participants are asked to read a brief excerpt from a news article prior to advancing to the survey questions. The following block contained both the control and treatment news excerpt, randomized so that an even number of participants were distributed to groups corresponding to the excerpt they received. Following this randomized block, participants completed the survey by first responding to statements that measure both their attitude toward climate change as national security ("Climate-Security") and their support for specific policy

\footnotetext{
${ }^{4}$ The Chair of the University of Louisville Institutional Review Board approved this study through the Expedited Review Procedure since this uses a survey method of data collection, which falls under Category 7 of 45 CFR 40,110(b). This study was also approved through 45 CFR 46.116 (C), which waives the requirement of a signed consent for the use of human subjects. The consent statement can be found with the entire survey instrument in the Appendix.
} 
options ("Policy-Action"). The survey concludes with a block that captures participants self-reported demographic information. Once completed, a final block is presented that displays a disclosure statement which explains the purpose of the survey and the framing method used. Also included in this final block is a random and anonymous four-digit identifier that participants entered into MTURK in order to prove survey completion, as this code is only available once the participant advances to the final block and release the payment once the submission was approved.

With the survey designed in Qualtrics and linked with MTRUK, the experiment was launched to all U.S. based MTURK "Workers". The following chapter, Chapter V, reports the demographic distribution among randomized groups, discusses the measurements used to test the hypotheses predicted in this thesis, and displays a series of statistical models that test the effects of a national security frame on climate change 


\section{CHAPTER V \\ DATA COLLECTION AND ANALYSIS}

This chapter reports the distribution of demographics between the control and treatment groups and tests the hypotheses described in Chapter II. Surprisingly, within one hour of posting the survey link to MTURK, 815 unique Workers had completed the HIT, which provides further proof to the rapid expansion of online labor markets. When researching the validity of MTURK as a social science tool, Paolacci et al (2010) waited nearly three weeks to obtain roughly one thousand survey participants. Once the HIT reached 800 completions it was removed from MTURK and the results were recorded on the Qualtrics platform.

Once all the completed surveys were recorded in Qualtrics, the data were recoded to give each response a numeric value. The first level of analysis was to compare the distribution of the participants demographic information across both experimental groups by cross-tabulating each demographic by group. The Pearson's chi-square statistics were calculated to test for independence between categorized variables. The first in a series of bar graphs, Figure 1 displays the distribution of self-identified political ideology among both the control and treatment groups. 
Figure 5.1

Distribution of Political Ideology between Experiment Groups.

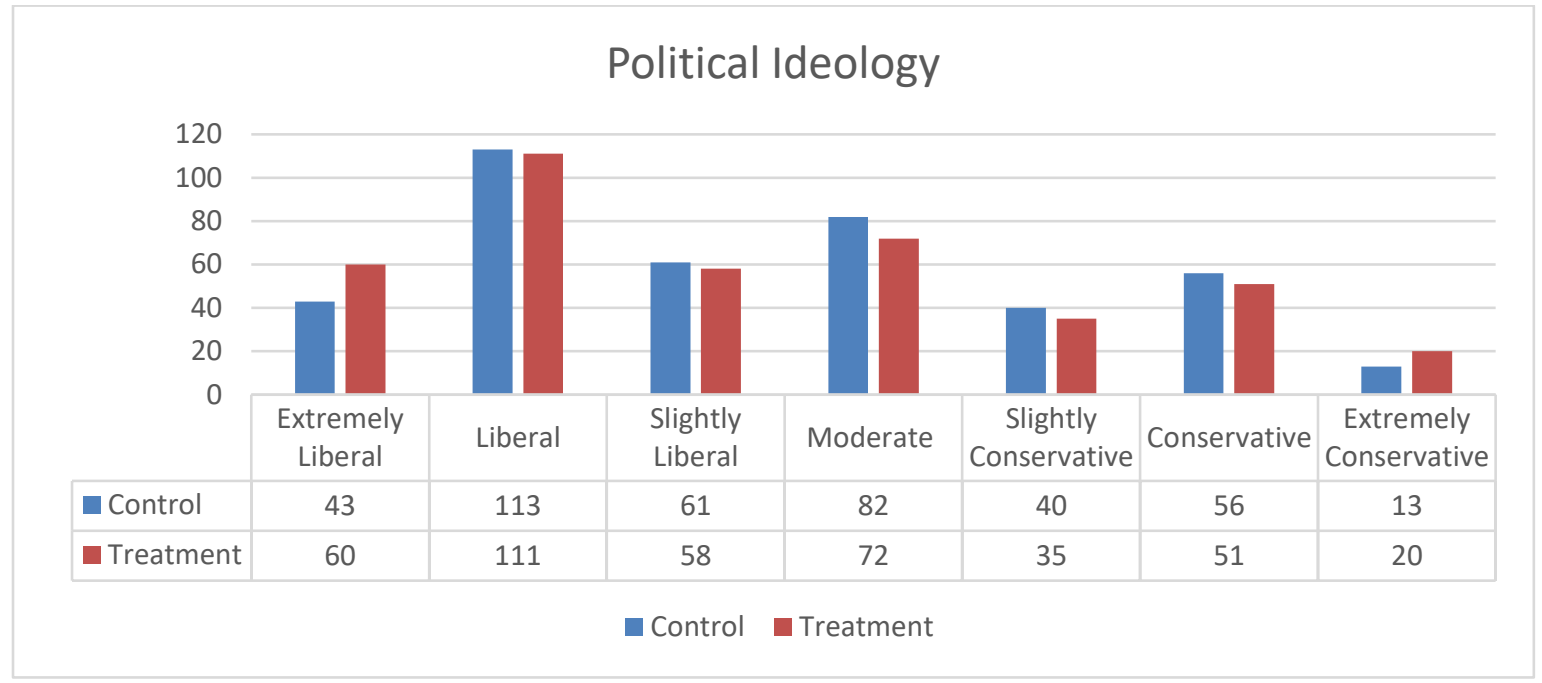

Pearson's Chi-Square $=5.59, \mathrm{p}=0.47$

Figure 1 shows only a slight variation in distribution between the randomized experimental groups, however, the Pearson's Chi-Square has a p value greater than 0.05 , which shows very little significant dependence between participation in either experiment group and one's self-identified political ideology. This lack of significance in the ChiSquare statistic shows no difference in the assignment to either experiment group based on a participant's political ideology. That is, a participant identifying as "Slightly Conservative", for example, had no impact on whether they fell into either the Control or Treatment group. Next, Figure 2 presents the distribution of Gender between the Control and Treatment groups. 
Figure 5.2

Distribution of Gender between Experiment Groups.

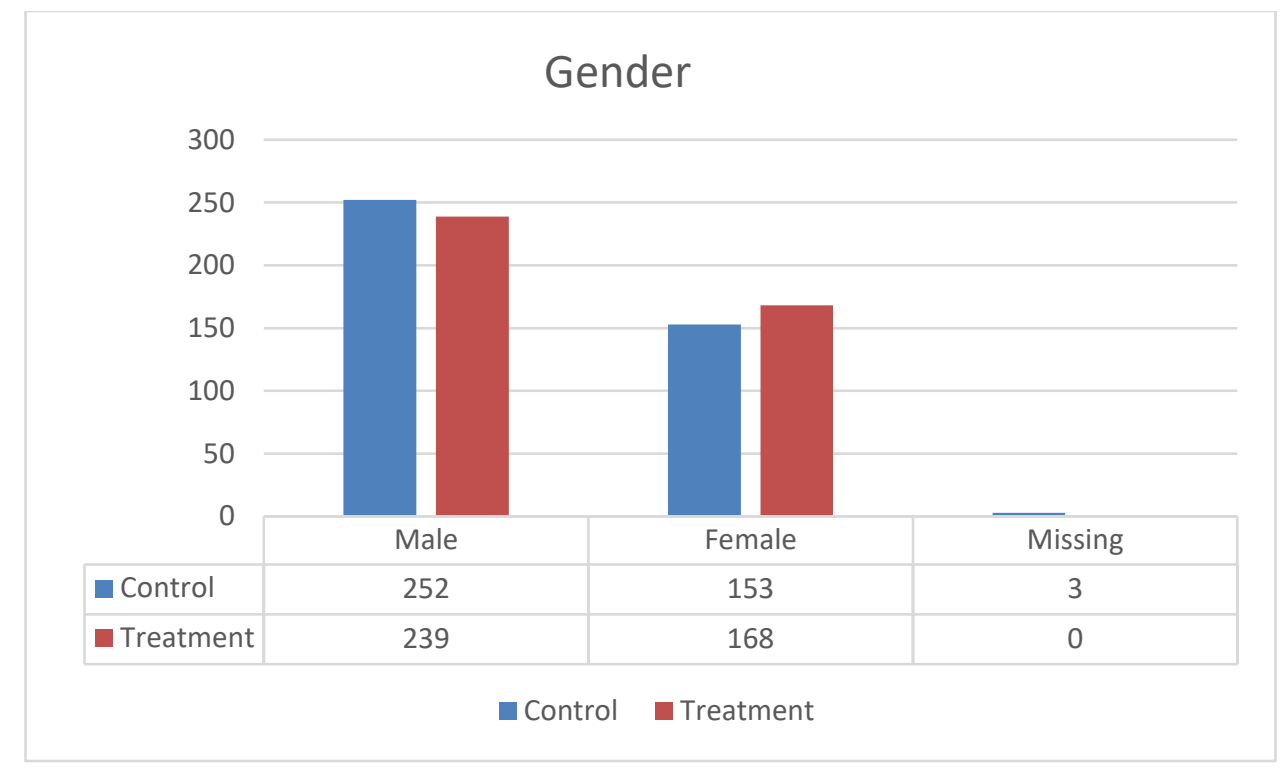

Chi-square $=1.04, \mathrm{p}=0.31$

Again, a cross-tabulation and calculation of the Pearson's Chi-Square on Gender and Experiment group shows only a slight variation among groups and a Chi-Square statistic well within the range to assume the variables are independent of one another. A p value of 0.31 is high enough to determine that there is no significant difference in the distribution of Gender among the Treatment and Control groups and both males and females had no difference in opportunity for representation in each group. Continuing along on demographics, Figure 3 presents the distribution of Age by Experiment group. 
Figure 3.

Distribution of Age between Experiment Groups.

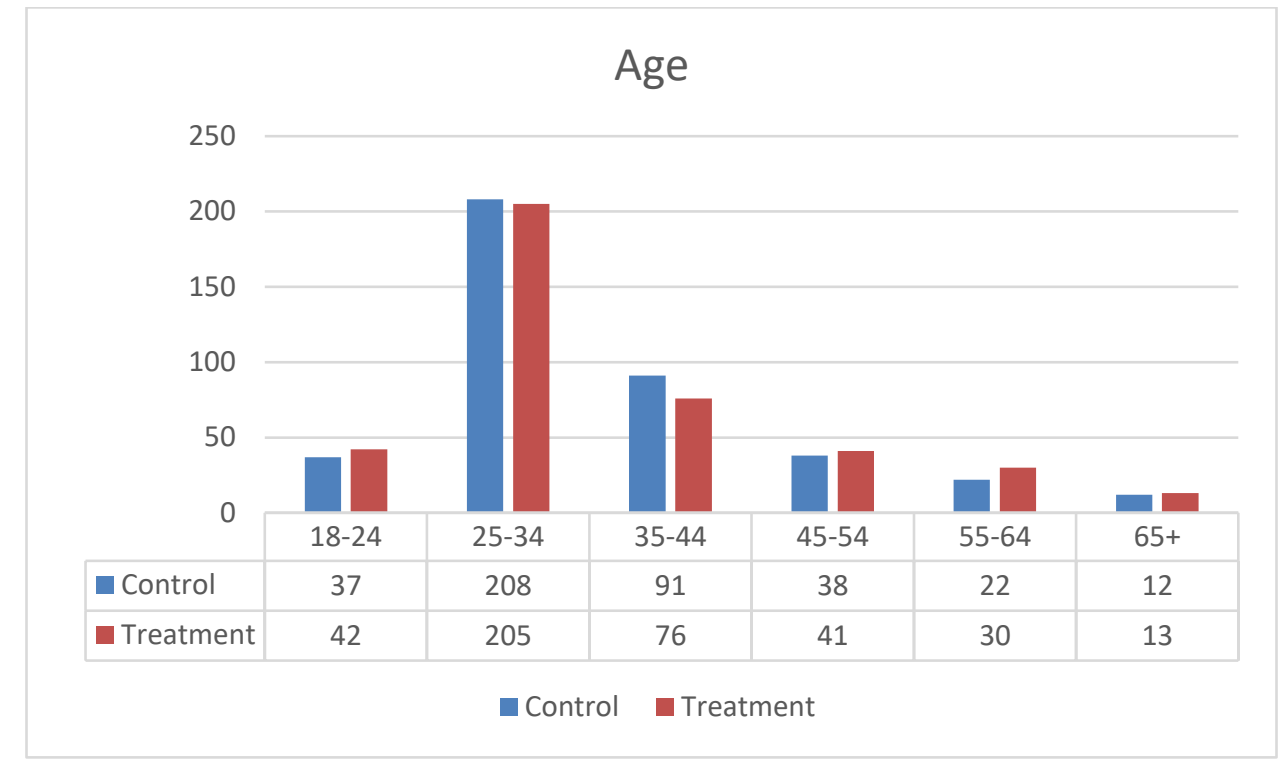

Pearson's Chi-Square $=3.07, \mathrm{p}=0.68$

The younger skew should not come as much surprise, given the very nature of online labor markets such as MTURK (Paolacci, et al 2010). While skewing young, the ChiSquare statistics shows that Age played no significant determining factor in the makeup of the experimental groups Next, Figure 4 presents the distribution of Race among experiment groups. 
Figure 4.

Distribution of Race between Experiment Groups.

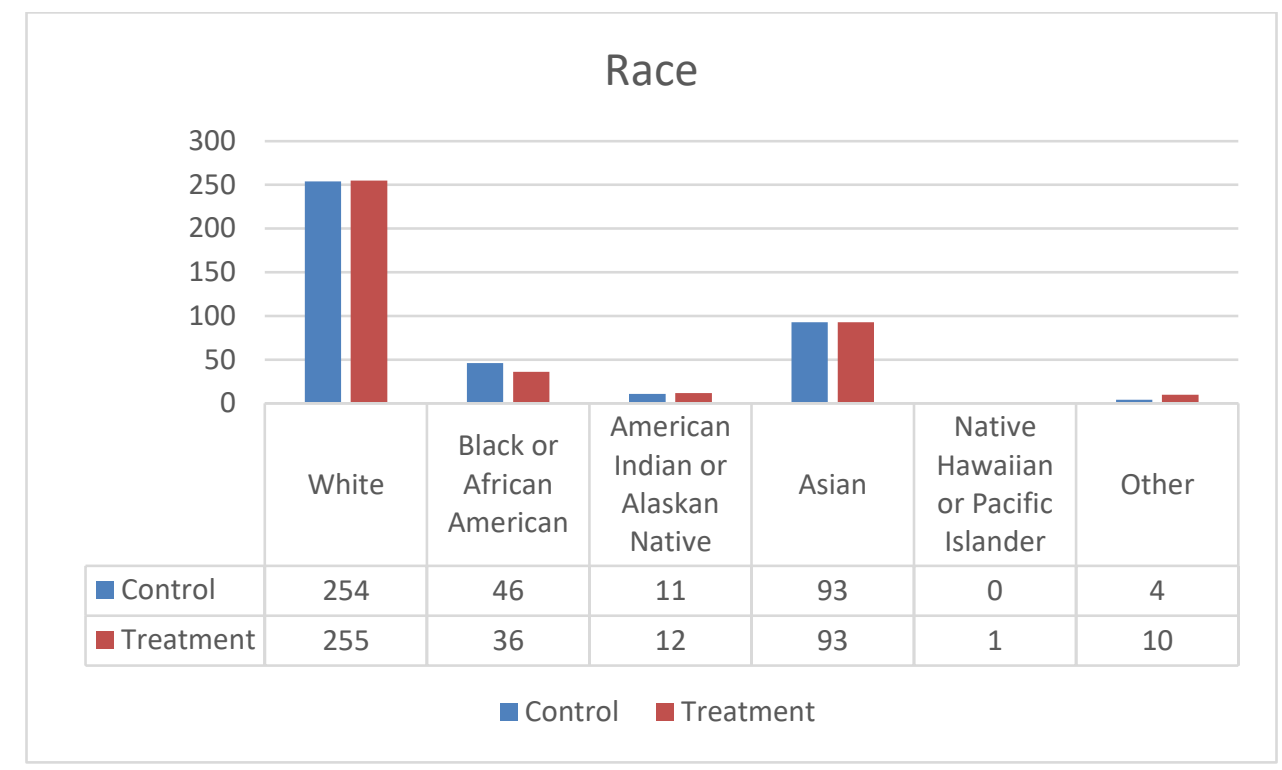

Pearson's Chi-Square $=4.84, \mathrm{p}=0.44$

Figure 4 displays an appropriate distribution and confirms independence between participants' Race and randomized experiment group and a Pearson's Chi-Square statistic well within the range to reject the Chi-Square hypothesis. Race and Experiment group are independent of one another and the $\mathrm{p}$ value indicates Race had no significant bearing on assignment to either the Control or Treatment group. Finally, Figure 5 presents the distribution of Education 
Figure 5.

Distribution of Education between Experiment Groups.

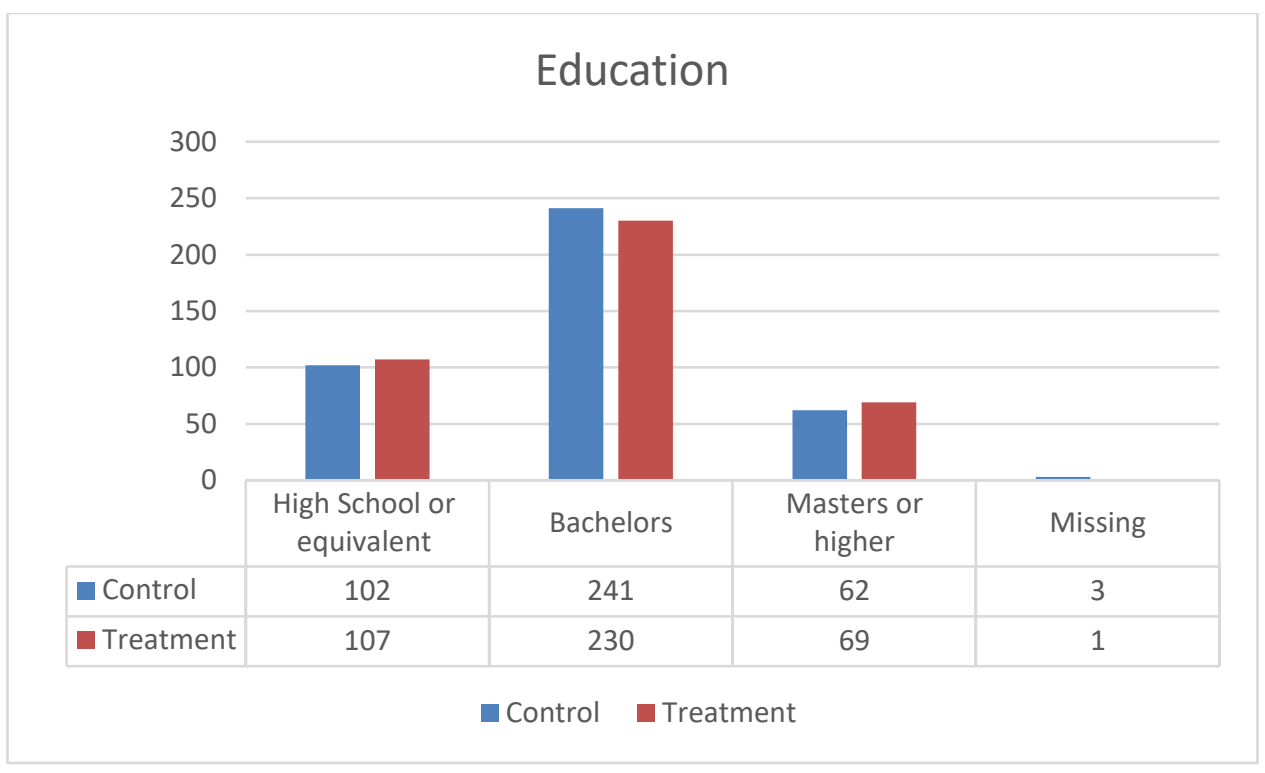

Pearson's Chi-Square $=0.075, \mathrm{p}=0.69$

As the demographic charts indicate, there is no statistical difference in the distribution of participant demographics among the control and treatment groups. Each crosstabulation of demographics by experiment group has a $\mathrm{p}$ value that far exceeds the .05 level, which allows for the rejection of the Chi-Square hypothesis that the variables were dependent upon on another. While the overall survey population skews younger, more educated, liberal, and white, the distributions between the control and treatment groups did not significantly differ and these demographics played no significant role in determining selection into either group

To test the hypotheses of this thesis, the survey is designed measure participants' perception of climate change as a matter of national security, as well support for specific 
policy actions, depending on the framing of an article the participants randomly received. Both areas, referred to as Climate-Security and Policy-Action, were measured within the same survey question block, in no particular order. Participants were asked to rank their level of agreement on a standard seven-point Likert scale (i.e. 1 Strongly Agree to 7 Strongly Disagree). Both areas were measured using three questions:

Climate change as national Security ("Climate-Security"):

Statement 1: "Climate change is a direct threat to national security."

Statement 2: "Rising sea-levels pose a severe risk to military readiness."

Statement 3: "Combating climate change is an effective way to improve national security."

\section{Support for Policy Action (“Policy-Action”):}

Statement 1: "The U.S. Government should invest more to reverse the adverse effect of climate change by raising taxes on wealthy individuals."

Statement 2: "Enacting environmental policies, such as renewable energy programs and 'green' infrastructure improvements, should be a government priority."

Statement 3: "Policymakers should consider placing a 'carbon tax' on carbon-emitting industries." 
With an encouraging distribution of demographic data and Pearson's Chi-Square showing independence among demographic variables and experiment groups, t-test analyses were conducted to test the hypotheses laid out in Chapter I. The null hypothesis of Hypothesis 1 predicts that the national security frame will make no significant difference on participants' perception of climate change as national security. To reject the null hypothesis, a t-test must show that there is a statistically significant difference between the mean of the Control Group and the mean of the Treatment Group. T-tests were conducted on each Climate-Security variable individually, with a final t-test conducted on a Climate-Security Index generated from combining the Climate-Security variables. Results of this t-test are reported in Table 5.1.

The results of Table 5.1 allow for the rejection of the null hypothesis of Hypothesis 1 and confirms, that when presented with the treatment frame of national security, survey participants are more likely to agree with statements in support of climate change as an issue of national security. Each of the three variables represent affirmative statements on climate change as an issue of national security. Although both groups were relatively supportive of the Climate-Security variables, the survey participants in the treatment groups received the national security frame and showed higher support for each of the three Climate-Security variables. Also, when indexed, the treatment group had a difference of means of +1.26 , significant at $\mathrm{p}<.001$. 
Table 5.1

Results of t-test and Descriptive Statistics for Climate-Security, by Experiment Group

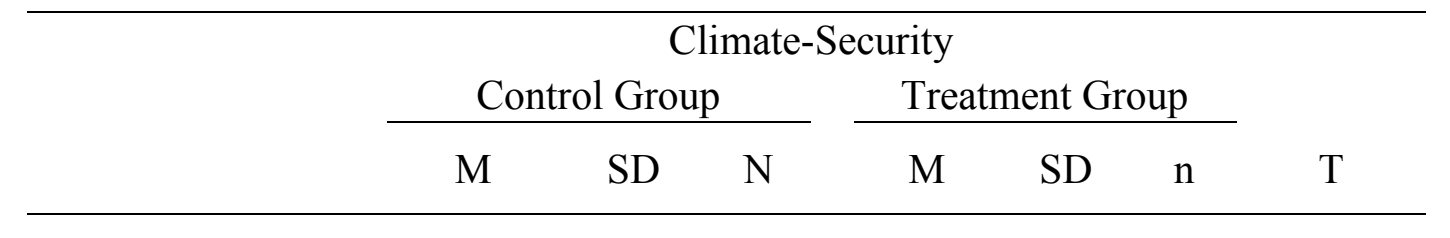

Rising sea-levels pose a severe risk to military

$\begin{array}{lllllll}5.19 & 1.53 & 407 & 5.69 & 1.29 & 407 & -5.09 * * *\end{array}$
readiness.

Climate change is a direct threat to $\begin{array}{lllllll}5.06 & 1.67 & 408 & 5.45 & 1.53 & 406 & -3.51 * * *\end{array}$ national security.

Combating climate change is an effective way to improve national

$\begin{array}{lllllll}4.93 & 1.67 & 408 & 5.29 & 1.55 & 406 & -3.29 * * *\end{array}$
security.

\section{Climate-Security} Index

$\begin{array}{lllllll}15.18 & 4.37 & 407 & 16.44 & 3.88 & 406 & -4.36^{* * *}\end{array}$

$* p \leq .1, * * p \leq .05, * * * p \leq .001$, two-tailed

The second hypothesis of this thesis predicted that participants given the treatment frame would be more likely to agree with policy options presented in the statements that make up the Policy-Action variable group. Just as with Hypothesis 1, a ttest was conducted to reject that null hypothesis that there is no significant difference in means between the control and treatment groups. The results of this t-test are reported in Table 5.2 for each of the Policy-Action variables, as well as an indexed variable. 
Table 5.2

Results of t-test and Descriptive Statistics for Policy-Action, by Experiment Group.

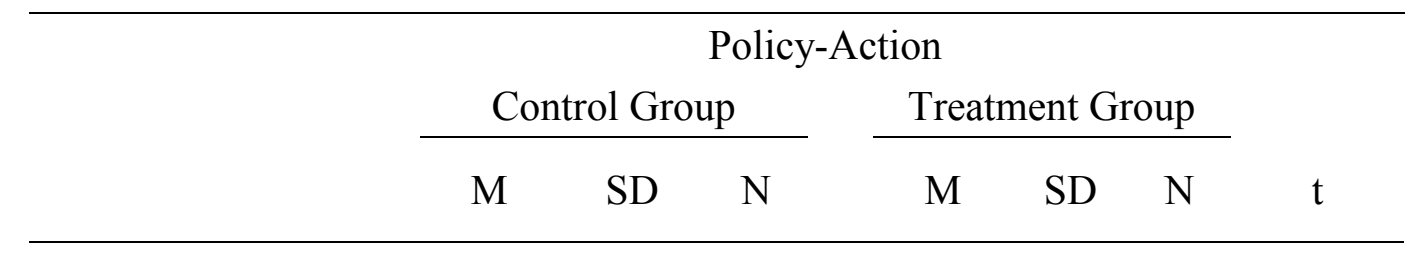

The U.S.

Government should

invest more to

$\begin{array}{llllllll}\text { reverse the adverse } & 5.12 & 1.84 & 408 & 5.35 & 1.77 & 407 & -1.83^{*}\end{array}$

effect of climate

change by raising

taxes on wealthy

individuals.

$\begin{aligned} & \text { Enacting } \\ & \text { environmental } \\ & \text { policies, such as } \\ & \text { renewable energy } \\ & \text { programs and }\end{aligned}$
'green'
infrastructure
improvements,
should be a
government priority.

Policymakers should consider placing a 'carbon tax' on carbon-emitting $\begin{array}{lllllll}5.36 & 1.69 & 408 & 5.54 & 1.62 & 406 & -1.52 *\end{array}$ industries.

Policy-Action Index $\quad 16.13 \quad 4.31 \quad 408 \quad 16.74 \quad 4.21 \quad 404 \quad-2.03^{* *}$

$* p \leq .1, * * p \leq .05, * * * p \leq .001$, two-tailed

Although the treatment frame had a more significant effect on the mean support for climate as security tested in Hypothesis 1, the results of the Hypothesis 2 t-test are 
significant enough to reject the null hypothesis. Survey participants were given three policy options and then asked for their level of support. Each Policy-Action variable has a mean that is significantly higher for the treatment group, who was given the national security frame, than for those participants in the control group without such a frame. There results were also confirmed when tested as an index of the variables. The PolicyAction index shows a 0.61 difference in means between the Control and Treatments groups, statistically significant at $\mathrm{p}<.05$.

With both hypotheses confirmed in Table 5.1 and Table 5.2, I conducted additional statistical models to control for the various demographic data also collected in the survey. Chapter II of this thesis included a review of the literature into both environmental and security attitudes that suggest that a security frame may have a larger effect on certain demographics, such as political ideology, race, and education (Konisky et al 2008, Severson and Coleman 2015). Table 5.3 presents the results of a t-test for the difference in means between the Control and Treatment groups on an index of both the Climate-Security and Policy Action variables when controlling for political ideology. 
Table 5.3

Results of t-tests and Descriptive Statistics Climate-Security and Policy-Action, by Experiment Group, controlled for Political Ideology.

\begin{tabular}{|c|c|c|c|c|c|c|}
\hline & \multicolumn{6}{|c|}{ Climate-Security Index \& Policy-Action Index } \\
\hline & \multicolumn{3}{|c|}{ Liberal } & \multicolumn{3}{|c|}{ Conservative } \\
\hline & M & SD & $\mathrm{N}$ & M & SD & $\mathrm{N}$ \\
\hline \multicolumn{7}{|l|}{$\begin{array}{l}\text { Climate-Security } \\
\text { Index }\end{array}$} \\
\hline Control & 16.24 & $3.44 * * *$ & 217 & 12.64 & $5.38 * *$ & 109 \\
\hline Treatment & 17.79 & $2.62 * * *$ & 228 & 14.35 & $4.95 * *$ & 106 \\
\hline \multicolumn{7}{|l|}{$\begin{array}{l}\text { Policy-Action } \\
\text { Index }\end{array}$} \\
\hline Control & 17.77 & $2.76 * *$ & 217 & 13.01 & 5.46 & 109 \\
\hline Treatment & 18.5 & $2.64 * *$ & 226 & 13.82 & 5.20 & 106 \\
\hline
\end{tabular}

Political ideology was measured in the survey on a seven-point scale ranging from 1 - "Extremely Liberal" to 7 - "Extremely Conservative". This variable was later categorized into two groups and survey participants that responded with "Moderate, Middle of the Road" were omitted from this t-test. The national security frame had a significant effect on both liberal and conservative participants on the Climate-Security perceptions, although this effect was not as strong for the policy options included in the Policy-Action Index, especially for conservatives. Unsurprisingly, liberals were more supportive of both the Climate-Security and Policy-Action variables. These findings show that participants who identify as Slightly to Extremely Conservative, when presented with a national security frame, are motivated to associated climate change with issues of national security. The lack of an effect this frame had on Policy-Action among conservatives is even more telling of their historic disdain for environmental issues. Even 
when presented with the national security frame, conservatives supported policy options at far lower rates that liberals. However, the use of the word "tax" in two of the three policy options may have presented an unintended frame, especially for conservatives. This finding may suggest that conservatives are averse to climate-mitigating policies when taxes are suggested. Next, Table 5.4 reports the results of a similar t-test that controls for Gender.

Table 5.4

Results of t-tests and Descriptive Statistics Climate-Security and Policy-Action, by Experiment Group, controlled for Gender.

\begin{tabular}{|c|c|c|c|c|c|c|}
\hline & \multicolumn{6}{|c|}{ Climate-Security Index \& Policy-Action Index } \\
\hline & \multicolumn{3}{|c|}{ Male } & \multicolumn{3}{|c|}{ Female } \\
\hline & $\mathrm{M}$ & SD & $\mathrm{N}$ & $\mathrm{M}$ & SD & $\mathrm{N}$ \\
\hline \multicolumn{7}{|l|}{$\begin{array}{l}\text { Climate-Security } \\
\text { Index }\end{array}$} \\
\hline Control & 15.28 & $4.57 * *$ & 252 & 15.05 & $4.05 * * *$ & 152 \\
\hline Treatment & 16.40 & $4.03 * *$ & 239 & 16.49 & $3.67 * * *$ & 167 \\
\hline \multicolumn{7}{|l|}{$\begin{array}{l}\text { Policy-Action } \\
\text { Index }\end{array}$} \\
\hline Control & 15.81 & $4.59 *$ & 252 & 16.69 & 3.79 & 153 \\
\hline Treatment & 16.57 & $4.39 *$ & 537 & 16.98 & 3.96 & 167 \\
\hline
\end{tabular}

While the security frame had little significant effect on the Policy-Action variables, it is significant in both Male and Female support for the Climate-Security variables. Moreover, these results show a high level of support for the Policy-Action variables when indexed. This finding supports others that show greater Female support for the issues surrounding climate change and the environmental overall. The following 
table, Table 5.5, reports the findings of a t-test that controls for Race. Figure 4 shows that a large majority of participant identified as White, therefore the Race variable has been categorized into White and Non-White. This is done not only to keep the distribution of these two categories comparable, but to separate the differing environmental views between Whites and Non-Whites as the literature (Abramowitz, 1980) suggests.

\section{Table 5.5}

Results of t-tests and Descriptive Statistics Climate-Security and Policy-Action, by Experiment Group, controlled for Race.

\begin{tabular}{|c|c|c|c|c|c|c|}
\hline & \multicolumn{6}{|c|}{ Climate-Security Index \& Policy-Action Index } \\
\hline & \multicolumn{3}{|c|}{ White } & \multicolumn{3}{|c|}{ Non-White } \\
\hline & M & $\mathrm{SD}$ & $\mathrm{N}$ & M & SD & $\mathrm{N}$ \\
\hline \multicolumn{7}{|l|}{$\begin{array}{l}\text { Climate-Security } \\
\text { Index }\end{array}$} \\
\hline Control & 14.30 & $4.71 * * *$ & 254 & 16.63 & $3.26^{* *}$ & 153 \\
\hline Treatment & 15.93 & $4.39 * * *$ & 254 & 17.29 & $2.64 * *$ & 152 \\
\hline \multicolumn{7}{|l|}{$\begin{array}{l}\text { Policy-Action } \\
\text { Index }\end{array}$} \\
\hline Control & 15.63 & $4.89^{*}$ & 254 & 16.97 & $2.97 *$ & 154 \\
\hline Treatment & 16.31 & $4.77 *$ & 253 & 17.46 & $2.93 *$ & 151 \\
\hline
\end{tabular}

Table 5.5 shows the national security frame had a much more significant effect on White survey participants than Non-White, both categories showed an increase in support for both variable groups when given the treatment. Overall, Non-White participants agreed more strongly with both the Climate-Security and Policy-Action variables, a further signal that demographics typically aligned with the Democratic party and liberal 
ideology express stronger support for the environment and mitigating polices. Table 5.6 controls for Age, which has already been shown in Figure 3 to skew younger, with $60 \%$ of participants under 35 . Therefore, Age was categorized into two groups, 18 to 34 years old and 35 years of age or older.

Table 5.6

Results of t-tests and Descriptive Statistics Climate-Security and Policy-Action, by Experiment Group, controlled for Age.

\begin{tabular}{|c|c|c|c|c|c|c|}
\hline & \multicolumn{6}{|c|}{ Climate-Security Index \& Policy-Action Index } \\
\hline & \multicolumn{3}{|c|}{$18-34$} & \multicolumn{3}{|c|}{$35+$} \\
\hline & M & $\mathrm{SD}$ & $\mathrm{N}$ & M & $\mathrm{SD}$ & $\mathrm{N}$ \\
\hline \multicolumn{7}{|l|}{$\begin{array}{l}\text { Climate-Security } \\
\text { Index }\end{array}$} \\
\hline Control & 15.93 & $3.68 * * *$ & 244 & 14.04 & $5.04 * *$ & 163 \\
\hline Treatment & 17.20 & $3.14 * * *$ & 247 & 15.25 & $4.57 * *$ & 159 \\
\hline \multicolumn{7}{|c|}{ Policy-Action Index } \\
\hline Control & 16.75 & $3.60 * *$ & 245 & 15.20 & 5.07 & 163 \\
\hline Treatment & 17.39 & $3.32 * *$ & 245 & 15.74 & 5.16 & 159 \\
\hline
\end{tabular}

The results in Table 5.6 shows a stronger support among younger participants for both variable groups, as well as a more significant difference in means when those 18 to 34 years old were presented with the treatment frame. The national security frame had no significant effect on support for the Policy-Action variables for participants 35 years of age or older. The final t-test in this series controls for education, which prior research would suggest higher support among both variable groups as the level of education increases. 
Overall, the results of the t-tests presented in Tables 1 through 7 strongly suggests that the treatment which framed climate change as an issue of national security had a significant effect on survey participant's perception of climate change and support for climate-mitigating policy action. The hypotheses tested in this chapter provide some explanation to the central research question of this thesis. This chapter concludes by presenting the results of OLS regression model that reports a coefficient for each control variable. This multivariate model offers a bit more explanation in the variance of support for the Climate-Security and Policy-Action variables by controlling for the variables that office competing explanations for this variance.

Table 5.8 reports these regression findings and shows that group assignment, that is whether a participant received the original news excerpt or the security framed treatment, had a positive relationship in determining support for the Climate-Security variables. Aside from the data reported in Table 5.1, Table 5.8 also affirms Hypothesis 1. Receiving the treatment frame is associated with a 1.21-point increase in agreement with the Climate-Security statements. The treatment frame also had a strong significant effect on the Policy-Action Index. Random selection into the treatment group is associated with a 0.54 increase for support for the policy options listed in the Policy-Action index. This finding is consistent with the bivariate results shown in Table 5.2, supporting the hypothesis that exposure to a nation security frame will increase levels of support for climate change policies. 
Table 5.7

Results of t-tests and Descriptive Statistics Climate-Security and Policy-Action, by Experiment Group, controlled for Education.

\begin{tabular}{|c|c|c|c|c|c|c|c|c|c|}
\hline & \multicolumn{3}{|c|}{ High School } & \multicolumn{3}{|c|}{ Bachelors } & \multicolumn{3}{|c|}{$\begin{array}{c}\text { Masters } \\
+\end{array}$} \\
\hline & M & SD & $\mathrm{N}$ & M & SD & $\mathrm{n}$ & M & SD & $\mathrm{n}$ \\
\hline $\begin{array}{l}\text { Climate-Securi } \\
\text { Index }\end{array}$ & & & & & & & & & \\
\hline Control & $\begin{array}{c}14.4 \\
0\end{array}$ & $4.75 * *$ & 102 & 15.17 & $4.25^{* * *}$ & 240 & 16.40 & 3.94 & 62 \\
\hline Treatment & $\begin{array}{c}15.9 \\
1\end{array}$ & $4.15^{* *}$ & 107 & 16.77 & $3.57 * * *$ & 230 & 16.16 & 4.41 & 68 \\
\hline $\begin{array}{l}\text { Policy-Action } \\
\text { Index }\end{array}$ & & & & & & & & & \\
\hline Control & 16.09 & 4.81 & 102 & 16 & $4.14 * * *$ & 241 & 16.65 & 4.20 & 62 \\
\hline Treatment & 16.38 & 4.57 & 106 & 17.17 & $3.78^{* * *}$ & 230 & 15.89 & 4.88 & 67 \\
\hline
\end{tabular}

$* p \leq .1, * * p \leq .05, * * * p \leq .001$, two-tailed

As suspected, Political Ideology also played a large role in support, or lack thereof, for both Climate-Security and Policy-Action, independent of group selection. As participants moved in ideology from the liberal to conservative category, ClimateSecurity saw a 0.89 reduction in agreement to the statements. Furthermore, as the t-test in Table 5.3 which controlled for Political Ideology showed, participants who identified as Slightly to Extremely Conservative reported little support for policy actions and shifting from left to right along the political spectrum is associated with a 1.21 reduction in support for policies. While these findings are assumed through a review of the literature into environmental polarization along political lines, significant reductions in support for policy actions, even when conservative participants are exposed to the national security frame, demonstrates just how large this divide remains. 
The regression model in Table 5.8 shows Gender with no statistically significant coefficient for either the Climate-Security or Policy-Action index. Although, as survey participants moved from Male to Female there is an associated increase in agreement with the statements of the study, Gender alone was not a significant factor in this increase. This finding suggests that women, in general, may be more receptive to climatemitigating policies, regardless of how the issue is framed. It is possible that this finding is a result of women identifying more as a liberal (Abramowitz, 1980; Dunlap \& McCright, 2000, 2011), making political ideology the leading factor for their increase in policy support.

Table 5.8 reports that Age had a significantly negative relationship with both Climate-Security and Policy-Action as the age of the participant increased. Agreement on the Climate-Security statements decreased by 0.38 as age increased. Similarly, agreement among the policy options in the Policy-Action index decreased by 0.48 . There are likely many factors which may explain why younger participants show stronger support for 
Table 5.8

Results of OLS Regression Model on Support for Climate-Security and Policy-Action by Control Variables.

\begin{tabular}{|c|c|c|}
\hline & Climate-Security Index & Policy-Action Index \\
\hline & $\begin{array}{l}\text { Coef. } \\
\text { (SE) }\end{array}$ & $\begin{array}{l}\text { Coef. } \\
\text { (SE) }\end{array}$ \\
\hline Political & $\begin{array}{l}-0.89 * * * \\
(0.08)\end{array}$ & $\begin{array}{l}-1.22 * * * \\
(0.07)\end{array}$ \\
\hline Gender & $\begin{array}{l}0.17 \\
(0.27)\end{array}$ & $\begin{array}{l}0.29 \\
(0.27)\end{array}$ \\
\hline Age & $\begin{array}{l}-0.48^{* * * *} \\
(0.12)\end{array}$ & $\begin{array}{l}-0.38^{* * *} \\
(.11)\end{array}$ \\
\hline Race & $\begin{array}{l}1.27 * * * \\
(0.28)\end{array}$ & $\begin{array}{l}0.75 * * \\
(0.28)\end{array}$ \\
\hline Education & $\begin{array}{l}0.41 * * \\
(0.21)\end{array}$ & $\begin{array}{l}0.00 \\
(0.20)\end{array}$ \\
\hline Group & $\begin{array}{l}1.21 * * * \\
(0.26)\end{array}$ & $\begin{array}{l}0.54 * * \\
(0.26)\end{array}$ \\
\hline Constant & $\begin{array}{l}18.50 \\
(0.85)\end{array}$ & $\begin{array}{l}20.84 \\
(0.79)\end{array}$ \\
\hline $\operatorname{Adj} R^{2}$ & 0.22 & 0.28 \\
\hline
\end{tabular}

Climate-Security and Policy-Action, but the primary difference, as with Gender, may be in their political ideology. As political parties are becoming more divided among age, the more liberal young population may be more reliable supporters of traditional Democratic Party issues. Younger participants will likely have to endure the more severe 
effects of climate change for many years to come, which may also be a contributing factor in their support.

Survey participants who self-identified as Non-White also reported a statistically significant increase in support for both Climate-Security and Policy-Action. Similar to Age and Gender, political ideology does seem to be a factor on Race, as being a NonWhite participant in this study was associated with an increase of 1.27 and 0.75 in support for Climate-Security and Policy-Action, respectively. As Whites are more aligned with conservative ideology and the Republican Party (Abramowitz, 1980; Dunlap \& McCright, 2000, 2011) their decreases in support to the statements in this study over Non-Whites is not surprising. However, the finding in Table 5.5 may suggest that receiving the national security frame may be the primary cause of any increased support among White participants.

Finally, participants' level of education had a significant positive regression coefficient for the Climate-Security Index while having also no relationship to the PolicyAction Index. As the level of participant education increased, their support for the Climate-Security statements increased by 0.41 . Education may be best summarized by the results in Table 5.7, showing not only insignificant difference in means between the control and treatment groups along Policy-Action, but an actual slight decrease in policy support when receiving the national security frame. As a participant's level of education increased, the security frame had no significant effect on the support for policy options, although it should be noted that participants with higher levels of education responded more supportively overall of the Policy-Action statements. 
The findings in Chapter V presented positive results from a large-N sample of online respondents to the central research question and hypotheses this thesis seeks out to test. Aside from the typical demographic skews that are expected in online labor markets, the distribution of demographics between the Control and Treatment groups proved adequate for comparison and a Chi-Square analysis confirmed independence among the variables. In nearly each T-test conducted, even when controlling for demographic variables, subjects receiving the national security frame showed a strong and significant increase in support for both Climate-Security and Policy-Action statements. In the conclusion of this thesis, Chapter VI discusses these findings in greater depth, the ways this study may impact framing studies, and how the rapid changes in communications and media may present future challenges to issue framers. 


\section{CHAPTER VI \\ DISCUSSION AND CONCLUSION}

The issues surrounding climate change continue to have a polarizing effect on many Americans. In this thesis I offer a potential bridge to this divide with a comprehensive study on how issue frames can shape public opinion, even on divisive issues. This division also lead me to the central research question presented in the Introduction: "Will the public perceive issues of climate change differently when they are framed as threats to national security?" To answer that question, this thesis employs an experimental survey method to measure the impact that security framing has on participant's perception of both climate change and environmental policy options. In this final chapter, I discuss the findings presented in Chapter V, offer suggestions on the direction of future research into environment-as-security given the findings of this thesis, and speculate about how the expansion of social media may present obstacles to issue framing.

For a national security frame to be successful in altering perceptions on climate change, the public must first be convinced that issues typically associated with climate change, rising sea levels in this case, are in fact matters of national security. To test the first hypothesis, statements that directly tie climate change to national security were given to survey participants asked to rank their level of agreement. Strong statistical evidence presented in Chapter V confirms this hypothesis that when presented with the treatment frame of national security, survey participants are more likely to agree with statements in support of climate change as an issue of national security. The statistical 
analysis reported in Table 5.1, shows an increased in support for the Climate-Security statements when participants received the national security news excerpt. Even when controlling for most demographic variables, the increase among treatment group participants held steady.

The data and analysis reported in Chapter V tells a very clear story on the current state of polarization in climate change perceptions. On average, participants selfidentifying as liberal perceive climate change as a matter of national security at a rate that far exceeds Conservatives. The demographic groups that are typically associated with these political ideologies present similar results. Young, non-white, and higher educated respondents all support the Climate-Security statements at greater levels than other groups. However, as the regression model in Table 5.8 shows, Political Ideology had the highest negative association with Climate-Policy support. The finding begs the questions as to what, if any, frame can be applied to climate change that would get Conservatives to change their perceptions on this issue.

Along with testing the effects of a national security frame on the public perceptions of climate change, I also sought out to test if such a frame would affect participants' support for particular climate mitigating policy options. After all, aside from an issue frame changing public perceptions, an additional goal of issue framers should be to foster action in support of their policy goals. Viewing climate change as a threat to national security alone will not satisfy this goal. Frames should also change perceptions of what should be done about the issue. To measure this support, participants ranked their level of agreement to three policy options. I find, that when presented with the national security frame, participants will increase their level of support for specific policy choices. 
Somewhat surprisingly, participants across both experiment groups were overall relatively supportive of the Policy-Action variables, although this support was higher among those who received the treatment frame, as hypothesized.

As with Hypothesis 1, increases in support for policy options was associated with more than just exposure to the treatment frame. Agreement with the Policy-Action statements can be viewed in a similar light was Climate-Security. Liberals, and related demographics such as young people, racial minorities, and those with higher levels of education showed higher support of policies, regardless of the frame the participant received. However, Conservatives may be been at an unintended disadvantage in support for the Policy-Action statements. Conservatives have historically been unmatched in their anti-tax attitudes (Abramowitz, 1980) and two of the three Policy-Action statements suggested imposing or raising taxes. With strongly significant findings that a national security frame increases perceptions that climate change is a matter of national security, future studies may look at additional policy areas to measure support. Rather than "Carbon-Tax" policy, conservatives may respond more supportive of a "Carbon-Offset" or "Tax Incentive" policy. These alternative policies to a "Carbon-Tax" could be applied to either individuals or corporations and by providing an incentive as opposed to a punishment, such alternatives may find some conservative support.

By confirming the hypotheses this thesis set out to test, framing climate change as national security may be a useful tool for media outlets, politicians, and advocacy groups to use to garner support in areas that traditionally shy away from such perceptions and policies. The review of media literature in Chapter II provides adequate evidence that sensational stories increase public attention and provide outlets with more incentive to 
run such stories. It may be hard to find a more sensational media story than one with national security as the focal point. This is not to say that policy messengers should adopt media strategies that stoke fear and anxiety in the public realm, and this thesis is not an endorsement of such a strategy. However, if the effects of climate change do not currently warrant such a dramatic frame, many indications suggest that they soon will as storms increase in intensity, drought and famine result in mass migrations, and military installations are affected by rising seas.

The use of a national security frame in discussing the effects of climate change may be most beneficial for politicians and issue advocacy groups. Liberals running for public office in conservative districts can beef up their national security bone fides without compromising traditional liberal stewardship for the environment. Groups advocating for environmental causes such as land use or renewable energy may be able to broaden their pool of supporters by embracing a national security frame, especially in areas with a heavy military presence which is typically along America's coasts.

Of course, for a media strategy that frames climate change as an issue of national security to reach the public at large and change perceptions on climate issues, these particular frames must find a receptive audience in an overcrowded media landscape. The vast expansion of media choice available to consumers has not had the effect on knowledge of political and policy issues some might expect. Regardless of this massive increase in media choice over the past few decades, political knowledge has remained constant over the same period of time (Prior, 2005). Rather than the evening news being the only program available to watch at a given time, hence providing all views with a singular issue frame, people are now able to selectively expose themselves to consume 
only the media messaging they prefer and frames that reinforce their ideological leanings. Conversely, this media environment also allows consumers to avoid everything else that strays away from their policy and policy comfort zone. Research into the public's media preferences does not bode well for producers of policy messages. When given the option to choose, only $5 \%$ of people prefer the news over other forms of programming, such as entertainment, while $34 \%$ rank the news at or near the bottom of their preference (Prior, 2005). This preference for entertainment over information should leave little doubt over the lack of growth in American's political knowledge and ability for some to respond to framing effects.

However, recent research does suggest that increased knowledge of policy issues can be seen in some segments of the public. The high-choice media environment has shown to increase political knowledge in those that are already knowledgeable but decreases among those with little knowledge to begin with, thus widening knowledge gap (Prior, 2005). This decrease among those who already lack knowledge may present one of the largest challenges to political actors attempting to control their preferred issue frame as they may be more susceptible to a frame that incites fear and uncertainty than those who are more in tune to the political environment.

Another factor leading to the increased knowledge gap of political issues as a result of the high-choice environment is the near elimination of passive learning through accidental exposure. When people are exposed to political information, even when accidental, they are able to retain some level of knowledge without having any interest in the topic (Prior, 2005). When the evening news was the only program on, viewers' only option was to watch or turn off the television, but when they do tune in knowledge can be 
gained. This is no longer the case with hundreds of channels, dozens of social media platforms, and thousands of websites competing for viewers by offering them the frames and issues that speak best to the consumer.

Even when people do seek out news and information over other, more popular, choices such as entertainment, they are often likely to do so through an ideological lens. As this thesis shows, perception of climate as security and support for climate change mitigating policies is determined as much by political ideology as the issue frame used in the experiment. When given the choice of news that either confirms or disagrees with their point of view, $43 \%$ of Americans prefer the source that reaffirms their ideological views, while only $24 \%$ of people actively seek out opposing viewpoints (Gainous \& Wagner, 2014). This phenomenon of selective exposure, as well as selective avoidance, sorts individuals and groups into information bubbles and echo-chambers, where only the information that confirms one's beliefs is consumed. These newly formed information bubbles and message echo chambers present possibly the greatest problems to issue framers moving forward, as some media consumers selectively expose themselves only to particular frames, likely presented through a political lens.

Although issue framers, media outlets, and the like may be at an increasing disadvantage in proliferating their preferred frame, this thesis makes it clear that issue frames are still an effective tool messengers can use to change public perception and foster support for particular policy goals. The survey experiment deployed and the confirmation of the hypotheses of this thesis suggests a national security frame may be a stronger tool than other frames when defining the effects of climate change. It is no stretch of the imagination that issues relating to climate change are issues of national 
security. After all, for a time in the recent past, this frame was the official position at the highest levels of government. It may take the widespread proliferation of this frame, as well as an ability to penetrate the information bubbles that are hindering public knowledge, for any meaningful action on climate change to become law. 


\section{REFERENCES}

Abramowitz, A. I. (1980). A Comparison of Voting for US Senator and Representative in 1978. American Political Science Review, 74(3), 633-640.

Aldrich, J. H., Gelpi, C., Feaver, P., Reifler, J., \& Sharp, K. T. (2006). Foreign policy and the electoral connection. Annu. Rev. Polit. Sci., 9, 477-502.

Allport, F. H., \& Lepkin, M. (1943). Building war morale with news-headlines. Public Opinion Quarterly, 7(2), 211-221.

Andrew, B. C. (2007). Media-generated shortcuts: Do newspaper headlines present another roadblock for low-information rationality? Harvard International Journal of Press/Politics, 12(2), 24-43.

Bennett, W. L. (2016). News: The politics of illusion. University of Chicago Press.

Berinsky, A. J., Huber, G. A., \& Lenz, G. S. (2012). Evaluating online labor markets for experimental research: Amazon. com's Mechanical Turk. Political analysis, 20(3), 351-368.

Bertolotti, M., \& Catellani, P. (2014). Effects of message framing in policy communication on climate change. European Journal of Social Psychology, 44(5), 474-486.

Boscarino, J. E. (2009). Surfing for problems: Advocacy group strategy in US forestry policy. Policy Studies Journal, 37(3), 415-434.

Boydstun, A. E., \& Glazier, R. A. (2013). A Two-Tiered Method for Identifying Trends in Media Framing of Policy Issues: The Case of the War on Terror. Policy Studies Journal, 41(4), 706-735

Brechin, S. R. (2010). 10 Public opinion: a cross-national view. Routledge handbook of climate change and society, 179.

Brooks, C., Dodson, K., \& Hotchkiss, N. (2010). National security issues and US presidential elections, 1992-2008. Social Science Research, 39(4), 518-526.

Carman, C. J. (1998). Dimensions of environmental policy support in the United States. Social Science Quarterly, 717-733.

Chandler, J., \& Shapiro, D. (2016). Conducting clinical research using crowdsourced convenience samples. Annual review of clinical psychology, 12.

Downs, A. (1972). Up and down with ecology: The issue-attention cycle. The public. 
Drotner, K. (2005). Media on the move: Personalized media and the transformation of publicness. Journal of Media Practice, 6(1).

Gainous, J., \& Wagner, K. M. (2013). Tweeting to power: The social media revolution in American politics. Oxford University Press.

Gans, H. J. (2004). Deciding what's news: A study of CBS evening news, NBC nightly news, Newsweek, and Time. Northwestern University Press.

Gifford, R., \& Comeau, L. A. (2011). Message framing influences perceived climate change competence, engagement, and behavioral intentions. Global Environmental Change, 21(4), 1301-1307.

Geer, J. G., \& Kahn, K. F. (1993). Grabbing attention: An experimental investigation of headlines during campaigns. Political Communication, 10(2), 175-191.

Gleick, P. H. (1991). Environment and security: The clear connections. Bulletin of the Atomic Scientists, 47(3), 16-21.

Gleick, P. H. (1993). Water and conflict: Fresh water resources and international security. International security, 18(1), 79-112.

Guth, J. L., Green, J. C., Kellstedt, L. A., \& Smidt, C. E. (1995). Faith and the environment: Religious beliefs and attitudes on environmental policy. American Journal of Political Science, 364-382.

Homer-Dixon, T. F. (1999). Environment, scarcity and conflict. Princeton Univer.

Iyengar, S. (1994). Is anyone responsible?: How television frames political issues. University of Chicago Press.

Iyengar, S. (1996). Framing responsibility for political issues. The Annals of the American Academy of Political and Social Science, 546(1), 59-70.

Kanagy, C. L., Humphrey, C. R., \& Firebaugh, G. (1994). Surging environmentalism: Changing public opinion or changing publics? Social Science Quarterly.

Keeter, S. (1993). Common Knowledge: News and the Construction of Political Meaning. Political Science Quarterly, 108(1), 197-199.

Klineberg, S. L., McKeever, M., \& Rothenbach, B. (1998). Demographic predictors of environmental concern: It does make a difference how it's measured. Social science quarterly, 734-753. 
Konisky, D. M., Milyo, J., \& Richardson, L. E. (2008). Environmental policy attitudes: Issues, geographical scale, and political trust. Social Science Quarterly, 89(5), 1066-1085.

Leiserowitz, A. (2007). International public opinion, perception, and understanding of global climate change. Human development report, 2008, 1-40.

Levay, K. E., Freese, J., \& Druckman, J. N. (2016). The demographic and political composition of Mechanical Turk samples. Sage Open, 6(1), 2158244016636433

Levy, M. A. (1995). Is the environment a national security issue?. International security, 20(2), 35-62.

Matthew, R. A. (2000). The environment as a national security issue. Journal of Policy History, 12(1), 101-122.

McComas, K., \& Shanahan, J. (1999). Telling stories about global climate change: Measuring the impact of narratives on issue cycles. Communication Research, 26(1), 30-57.

McCright, A. M., \& Dunlap, R. E. (2000). Challenging global warming as a social problem: An analysis of the conservative movement's counter-claims. Social problems, 47(4), 499- 522.

McCright, A. M., \& Dunlap, R. E. (2011). The politicization of climate change and polarization in the American public's views of global warming, 2001-2010. The Sociological Quarterly, 52(2), 155-194.

McCright, A. M., Dunlap, R. E., \& Marquart-Pyatt, S. T. (2016). Political ideology and views about climate change in the European Union. Environmental Politics, 25(2), 338-358.

McQuail, D. (1994). Mass communication theory: An introduction, Thousand Oak.

Merry, M. K. (2013). Framing environmental disaster: Environmental advocacy and the Deepwater Horizon oil spill. Routledge.

Morton, T. A., Rabinovich, A., Marshall, D., \& Bretschneider, P. (2011). The future that may (or may not) come: How framing changes responses to uncertainty in climate change communications. Global Environmental Change, 21(1), 103-109.

Mueller, J. E. (1970). Presidential Popularity from Truman to Johnson 1. American Political Science Review, 64(1), 18-34.

Mullinix, K. J., Leeper, T. J., Druckman, J. N., \& Freese, J. (2015). The generalizability of survey experiments. Journal of Experimental Political Science, 2(2), 109-138. 
Paolacci, G., Chandler, J., \& Ipeirotis, P. G. (2010). Running experiments on amazon mechanical turk.

Pfau, M. R. (1995). Covering urban unrest: The headline says it all. Journal of Urban Affairs, 17(2), 131-141.

Prior, M. (2005). News vs. entertainment: How increasing media choice widens gaps in political knowledge and turnout. American Journal of Political Science, 49(3), $577-592$.

Reber, B. H., \& Berger, B. K. (2005). Framing analysis of activist rhetoric: How the Sierra Club succeeds or fails at creating salient messages. Public Relations Review, 31(2), 185-195.

Rochefort, D. A., \& Cobb, R. W. (1993). Problem definition, agenda access, and policy choice. Policy studies journal, 21(1), 56-71.

Scheufele, D. A. (1999). Framing as a theory of media effects. Journal of communication, 49(1), 103-122.

Severson, A. W. \& Coleman, E. A. (2015), Moral Frames and Climate Change Policy Attitudes. Social Science Quarterly, 96(2): 1277-1290

Sheafer, T. (2006). How to evaluate it: The role of story-evaluative tone in agenda setting and priming. Journal of Communication, 57(1), 21-39.

Smith, A. (1996). Diversionary foreign policy in democratic systems. International Studies Quarterly, 40(1), 133-153.

Smith, E. J., \& Fowler Jr, G. L. (1982). How comprehensible are newspaper headlines?.

Stone, D. A. (1989). Causal stories and the formation of policy agendas. Political science quarterly, 104(2), 281-300.

Tannenbaum, P. H. (1953). The effect of headlines on the interpretation of news stories. Journalism Bulletin, 30(2), 189-197.

Scheufele, D. A. (1999). Framing as a theory of media effects. Journal of communication, 49(1), 103-122.

Worland, J. \& Johnson, D. (2016, March 14) "See How Your City May Be Affected By Rising Sea Levels" TIME.com. Retrieved from http://time.com/4257194/sealevel-rise-climate-change-miami/.

Xiao, C., \& Dunlap, R. E. (2007). Validating a comprehensive model of environmental concern cross-nationally: A US-Canadian comparison. Social science quarterly, 88(2), 471-493. 


\section{APPENDIX}

\section{Control Excerpt:}

\section{Millions Along U.S. Coasts Will Be Affected}

Study after study has shown that sea-level rise due to climate change will leave cities on U.S. coasts vulnerable to severe and more frequent flooding. Despite the warnings, though, Americans continue to live and build in regions likely to be inundated with water in a matter of decades.

New research published in the journal Nature Climate Change suggests that as many as 13 million people may live in vulnerable regions along the U.S. coasts by 2100 if sea levels rise by 5.9 feet $(1.8 \mathrm{~m})$. That's three times as many people as would be affected in the absence of continued coastal development and anticipated population growth along the sea.

"By their nature populations are always changing," says study author Matt Hauer, a demographer at the University of Georgia. "If we don't have adapted infrastructure to protect people vulnerable to sea level rise, we could see a migration that mirrors the Great Migration"- the period in the U.S. during the 20th century when millions of Americans moved to cities in the North. 


\section{Treatment Excerpt: National Security Frame}

\section{Millions Along U.S. Coasts Will be Affected, Threatening National Security}

Study after study has shown that sea-level rise due to climate change will leave military instillations on U.S. coasts vulnerable to severe and more frequent flooding. Despite the warnings, though, America's military continues to build and operate in regions likely to be inundated with water in a matter of decades.

New research published in the journal Nature Climate Change suggests that as many as 13 million people, many of them active-duty service members and their families scattered across nearly 130 coastal military bases, may live in vulnerable regions along the U.S. coasts by 2100 if sea levels rise by 5.9 feet $(1.8 \mathrm{~m})$. That's three times as many military personnel as would be affected in the absence of continued coastal development and anticipated population growth along the sea.

"By their nature military operations are always changing," says study author Matt Hauer, a researcher at the University of Georgia. "If we don't have adapted infrastructure to protect the military personnel and equipment vulnerable to sea level rise, we could see a migration that mirrors the Great Migration"- the period in the U.S. during the 20th century when millions of Americans moved to cities in the North." The effects of such an event may pose an irreversible threat to military readiness and national security. 


\section{$\underline{\text { Survey Instrument }}$}

\section{Start of Block: Default Question Block}

Dear Participant:

You are being invited to participate in a research study by answering questions in the attached survey about your attitudes toward climate change. This study is conducted by researchers from the University of Louisville. There are no known risks for your participation in this research study. The information collected may not benefit you directly. The information learned in this study may be helpful to others. The information you provide will contribute to our understanding of climate change attitudes. Your completed survey will be stored at the University of Louisville, Department of Political Science. The survey will take approximately 10 minutes time to complete. You will be credited $\$ 0.50$ on your MTurk account 2-3 days following completion of the task.

Individuals from the Department of Political Science, the Institutional Review Board (IRB), the Human Subjects Protection Program Office (HSPPO), and other regulatory agencies may inspect these records. In all other respects, however, the data will be held in confidence to the extent permitted by law. Should the data be published, your identity will not be disclosed.

Taking part in this study is voluntary. By answering survey questions, you agree to take part in this research study. You do not have to answer any questions that make you uncomfortable. You may choose not to take part at all. If you decide to be in this study, you may stop taking part at any time. If you decide not to be in this study or if you stop taking part at any time, you will not lose any benefits for which you may qualify.

If you have any questions, concerns, or complaints about the research study, please contact: Dr. Jason Gainous at 502-852-1660 or jason.gainous@louisville.edu. If you have any questions about your rights as a research subject, you may call the Human Subjects Protection Program Office at (502) 852-5188. You can discuss any questions about your rights as a research subject, in private, with a member of the Institutional Review Board (IRB). You may also call this number if you have other questions about the research, and you cannot reach the research staff, or want to talk to someone else. The IRB is an independent committee made up of people from the University community, staff of the institutions, as well as people from the community not connected with these institutions. The IRB has reviewed this research study.

If you have concerns or complaints about the research or research staff and you do not 
wish to give your name, you may call 1-877-852-1167. This is a 24-hour hot line answered by people who do not work at the University of Louisville.

\section{End of Block: Default Question Block}

\section{Start of Block: Block 5}

Please read the following brief news excerpt before proceeding the survey questions.

\section{End of Block: Block 5}

\section{Start of Block: Block 2}

\section{*Questions in this block were randomized to present only one of the elements below. These elements were evenly presented to participants.}

\section{Millions Along U.S. Coasts Will Be Affected}

Study after study has shown that sea-level rise due to climate change will leave cities on U.S. coasts vulnerable to severe and more frequent flooding. Despite the warnings, though, Americans continue to live and build in regions likely to be inundated with water in a matter of decades.

New research published in the journal Nature Climate Change suggests that as many as 13 million people may live in vulnerable regions along the U.S. coasts by 2100 if sea levels rise by 5.9 feet $(1.8 \mathrm{~m})$. That's three times as many people as would be affected in the absence of continued coastal development and anticipated population growth along the sea.

"By their nature populations are always changing," says study author Matt Hauer, a demographer at the University of Georgia. "If we don't have adapted infrastructure to protect people vulnerable to sea level rise, we could see a migration that mirrors the Great Migration"- the period in the U.S. during the 20th century when millions of Americans moved to cities in the North

\section{Millions Along U.S. Coasts Will be Affected, Threatening National Security}

Study after study has shown that sea-level rise due to climate change will leave military installations on U.S. coasts vulnerable to severe and more frequent flooding. Despite the warnings, though, America's military continues to build and operate in regions likely to 
be inundated with water in a matter of decades.

New research published in the journal Nature Climate Change suggests that as many as 13 million people, many of them active-duty service members and their families scattered across nearly 130 coastal military bases, may live in vulnerable regions along the U.S. coasts by 2100 if sea levels rise by 5.9 feet $(1.8 \mathrm{~m})$. That's three times as many military personnel as would be affected in the absence of continued coastal development and anticipated population growth along the sea.

"By their nature military operations are always changing," says study author Matt Hauer, a researcher at the University of Georgia. "If we don't have adapted infrastructure to protect the military personnel and equipment vulnerable to sea level rise, we could see a migration that mirrors the Great Migration"- the period in the U.S. during the 20th century when millions of Americans moved to cities in the North." The effects of such an event may pose an irreversible threat to military readiness and national security.

\section{End of Block: Block 2}

Start of Block: Block 3

Please read the following statements and select the option that best matches your attitudes toward climate change.

Rising sea-levels pose a severe risk to military readiness.

Strongly agree

Agree

Somewhat agree

Neither agree nor disagree

Somewhat disagree

Disagree

Strongly disagree 
The U.S. government should invest more to reverse the adverse effects of climate change by raising taxes on wealthy individuals.

Strongly agree

Agree

Somewhat agree

Neither agree nor disagree

Somewhat disagree

Disagree

Strongly disagree

Climate change is a direct threat to U.S. national security.

Strongly agree

Agree

Somewhat agree

Neither agree nor disagree

Somewhat disagree

Disagree

Strongly disagree 
Enacting environmental policies, such as renewable energy programs and "green" infrastructure improvements, should be a government priority.

Strongly agree

Agree

Somewhat agree

Neither agree nor disagree

Somewhat disagree

Disagree

Strongly disagree

Combating climate change is an effective way to improve national security.

Strongly agree

Agree

Somewhat agree

Neither agree nor disagree

Somewhat disagree

Disagree

Strongly disagree 
Policy makers should consider placing a "carbon tax" on carbon-emitting industries.

Strongly agree

Agree

Somewhat agree

Neither agree nor disagree

Somewhat disagree

Disagree

Strongly disagree

End of Block: Block 3

Start of Block: Block 4

Finally, please select the demographic information that best describes you.

Political Ideology

Extremely Liberal

Liberal

Slightly Liberal

Moderate, Middle of Road

Slightly Conservative

Conservative

Extremely Conservative 
Gender

Male

Female

Age

$18-24$

$25-34$

$35-44$

$45-54$

$55-64$

$65+$

Race/Ethnicity

White

Black or African American

American Indian or Alaska Native

Asian

Native Hawaiian or Pacific Islander

Other 
Highest Level of Education

High school graduate, diploma, or the equivalent

Bachelors degree

Masters degree or higher

End of Block: Block 4 


\section{CURRICULUM VITAE}

NAME: $\quad$ Adam Lyons

ADDRESS: 2912 Westfield Rd.

Louisville, KY 40220

EDUCATION:

B.S., Political Science

University of Louisville

2011

M.A., Political Science

University of Louisville

2018

PROFESSIONAL EXPERIENCE:

Project Manager

Office of Housing and Community Development

Develop Louisville/Louisville Forward

Louisville/Jefferson County Metro Government

Louisville, KY 12/1/2015-Present

I\&FP Senior Project Administrator

Infrastructure and Flood Projection Division

Metropolitan Sewer District

Louisville, KY 5/7/2012-12/1/2015

Legislative Assistant (Internship)

Legislative Research Commission

Kentucky General Assembly

Frankfort, KY 1/1/2009-5/1/2009

PROFESSIONAL CERTIFICATIONS:

Housing Development Financial Professional (HDFP)

National Development Council

2018 